\title{
Triapine Derivatives Act as Copper Delivery Vehicles to Induce Deadly Metal Overload in Cancer Cells
}

\author{
Kateryna Ohui ${ }^{1,+}{ }^{+}$Iryna Stepanenko ${ }^{1, *,+}$, Iuliana Besleaga ${ }^{1}$, Maria V. Babak ${ }^{2,3}{ }^{\circledR}$, Radu Stafi ${ }^{1}$, \\ Denisa Darvasiova ${ }^{4}$, Gerald Giester ${ }^{5}$, Vivien Pósa ${ }^{6,7}$, Eva A. Enyedy ${ }^{6,7}(0)$, Daniel Vegh ${ }^{8}$, \\ Peter Rapta ${ }^{4}$, Wee Han Ang ${ }^{2}$, Ana Popović-Bijelić ${ }^{9}{ }^{\circledR}$ and Vladimir B. Arion ${ }^{1, *}$ \\ 1 Institute of Inorganic Chemistry, University of Vienna, Währinger Strasse 42, A-1090 Vienna, Austria; \\ kateryna.ohui@univie.ac.at (K.O.); besleaga.iuliana04@gmail.com (I.B.); radustafi@gmail.com (R.S.) \\ 2 Department of Chemistry, National University of Singapore, 3 Science Drive 2, Singapore 117543, Singapore; \\ ang.weehan@nus.edu.sg \\ 3 Department of Chemistry, City University of Hong Kong, 83 Tat Chee Avenue, \\ Hong Kong SAR 999077, China; mbabak@cityu.hk.edu \\ 4 Institute of Physical Chemistry and Chemical Physics, Slovak University of Technology in Bratislava, \\ Radlinského 9, SK-81237 Bratislava, Slovakia; denisa.darvasiova@stuba.sk (D.D.); peter.rapta@stuba.sk (P.R.) \\ 5 Department of Mineralogy and Crystallography, University of Vienna, Althan Strasse 14, \\ A-1090 Vienna, Austria; gerald.giester@univie.ac.at \\ 6 Department of Inorganic and Analytical Chemistry, Interdisciplinary Excellence Centre, University of Szeged, \\ Dóm tér 7, H-6720 Szeged, Hungary; posavivien@gmail.com (V.P.); enyedy@chem.u-szeged.hu (E.A.E.) \\ 7 MTA-SZTE Lendület Functional Metal Complexes Research Group, University of Szeged, Dóm tér 7, \\ H-6720 Szeged, Hungary \\ 8 Institute of Organic Chemistry, Catalysis and Petrochemistry, Department of Organic Chemistry, \\ Slovak University of Technology in Bratislava, Radlinského 9, SK-81237 Bratislava, Slovakia; \\ daniel.vegh@stuba.sk \\ 9 Faculty of Physical Chemistry, University of Belgrade, 11158 Belgrade, Serbia; ana@ffh.bg.ac.rs \\ * Correspondence: iryna.stepanenko@univie.ac.at (I.S.); vladimir.arion@univie.ac.at (V.B.A.) \\ + Both co-authors contributed equally.
}

Received: 21 August 2020; Accepted: 15 September 2020; Published: 19 September 2020

Abstract: Thiosemicarbazones continue to attract the interest of researchers as potential anticancer drugs. For example, 3-aminopyridine-2-carboxaldehyde thiosemicarbazone, or triapine, is the most well-known representative of this class of compounds that has entered multiple phase I and II clinical trials. Two new triapine derivatives $\mathbf{H L}^{1}$ and $\mathbf{H L}^{2}$ were prepared by condensation reactions of 2-pyridinamidrazone and S-methylisothiosemicarbazidium chloride with 3-N-(tert-butyloxycarbonyl) amino-pyridine-2-carboxaldehyde, followed by a Boc-deprotection procedure. Subsequent reaction of $\mathbf{H L}^{1}$ and $\mathbf{H L}^{2}$ with $\mathrm{CuCl}_{2} \cdot 2 \mathrm{H}_{2} \mathrm{O}$ in $1: 1$ molar ratio in methanol produced the complexes $\left[\mathbf{C u}{ }^{\mathrm{II}}\left(\mathbf{H L}^{1}\right) \mathbf{C l}_{\mathbf{2}}\right] \cdot \mathbf{H}_{\mathbf{2}} \mathbf{O}\left(\mathbf{1} \cdot \mathbf{H}_{\mathbf{2}} \mathrm{O}\right)$ and $\left[\mathrm{Cu}^{\mathrm{II}}\left(\mathbf{H L}^{\mathbf{2}}\right) \mathbf{C l}_{\mathbf{2}}\right]$ (2). The reaction of $\mathbf{H L}^{2}$ with $\mathrm{Fe}\left(\mathrm{NO}_{3}\right)_{3} \cdot 9 \mathrm{H}_{2} \mathrm{O}$ in 2:1 molar ratio in the presence of triethylamine afforded the complex $\left[\mathrm{Fe}^{\mathrm{III}}\left(\mathrm{L}^{\mathbf{2}}\right)_{2}\right] \mathrm{NO}_{3} \cdot \mathbf{0 . 7 5} \mathrm{H}_{\mathbf{2}} \mathrm{O}$ $\left(\mathbf{3} \cdot \mathbf{0 . 7 5} \mathrm{H}_{2} \mathrm{O}\right)$, in which the isothiosemicarbazone acts as a tridentate monoanionic ligand. The crystal structures of $\mathbf{H L}^{1}, \mathbf{H L}^{2}$ and metal complexes $\mathbf{1}$ and $\mathbf{2}$ were determined by single crystal X-ray diffraction. The UV-Vis and EPR spectroelectrochemical measurements revealed that complexes 1 and 2 underwent irreversible reduction of $\mathrm{Cu}$ (II) with subsequent ligand release, while $\mathbf{3}$ showed an almost reversible electrochemical reduction in dimethyl sulfoxide (DMSO). Aqueous solution behaviour of $\mathbf{H L}^{\mathbf{1}}$ and $\mathbf{1}$, as well as of $\mathbf{H L}^{\mathbf{2}}$ and its complex 2, was monitored as well. Complexes 1-3 were tested against ovarian carcinoma cells, as well as noncancerous embryonic kidney cells, in comparison to respective free ligands, triapine and cisplatin. While the free ligands $\mathbf{H L}^{\mathbf{1}}$ and $\mathbf{H L}^{2}$ were devoid of antiproliferative activity, their respective metal complexes showed remarkable antiproliferative activity in a micromolar concentration range. The activity was not related to the inhibition of ribonucleotide reductase (RNR) R2 protein, but rather to cancer cell homeostasis disturbance-leading to the disruption of cancer cell signalling. 
Keywords: triapine; amidrazones; isothiosemicarbazones; copper(II); iron(III); cancer signalling

\section{Introduction}

$\alpha-\mathrm{N}$-Heterocyclic thiosemicarbazones (TSCs) attract considerable attention since their remarkable antiproliferative properties have been discovered [1]. The most promising representative of this group of compounds is 3-aminopyridine-2-carboxaldehyde thiosemicarbazone or triapine (3-AP), which has already entered more than 30 phase I and II clinical trials [2-4]. 3-AP was also tested in various combination regimens and was shown to enhance the activity of other anticancer drugs, such as cisplatin [2,5], gemcitabine [6], doxorubicin [7], irinotecan [4]. It is believed that the mode of action of 3-AP is based on the effective inhibition of RNR [8-10] as a result of Fe(II) chelation from the diferric-tyrosyl cofactor, followed by the generation of reactive oxygen species (ROS) [11]. However, despite the promising anticancer effects in vitro and in vivo, the use of 3-AP in patients is associated with side-effects, i.e., neutropenia [12], methemoglobinemia [13], nausea, vomiting etc. Additionally, several types of solid tumours demonstrated resistance to 3-AP treatment [12,14-16]. TSCs are known to efficiently chelate first-row transition metals, 3-AP, and its analogues were coordinated to endogenous metals, such as $\mathrm{Cu}$ and Fe [17-20]. TSC coordination to essential metals often decreases overall toxicity of the drug molecules [21] and increases their anticancer activity, due to the synergistic action of TSCs and the metal centre [19-21]. In general, numerous $\mathrm{Cu}(\mathrm{II})$ complexes of thiosemicarbazones were characterised by superior anticancer activity when compared to that of the free ligands [22-26]. In contrast, coordination to Fe(III) prior to the administration of the compound did not always result in the improvement of cytotoxicity [17,27]. Interestingly, both $\mathrm{Cu}(\mathrm{II})$ and $\mathrm{Fe}(\mathrm{III})$ complexes of 3-AP were less active than 3-AP itself $[10,17]$, possibly due to their high thermodynamic stability and lower cell uptake kinetics [28].

Carboxamidrazones structurally resemble thiosemicarbazones, but, surprisingly, their anticancer effects were not extensively studied. These compounds demonstrated antiproliferative activity in the micromolar range and good selectivity to cancer cells over healthy cells $[29,30]$. Similarly to $\mathrm{Cu}$ (II)-TSC complexes, coordination of carboxamidrazones to $\mathrm{Cu}(\mathrm{II})$ improved the cytotoxicity. However, there are only several examples of reported $\mathrm{Cu}(\mathrm{II})$-carboxamidrazone complexes [31-33]. Therefore, we have prepared novel pyridinamidrazone and S-methylisothiosemicarbazone, structurally related to 3-AP, as well as $\mathrm{Cu}$ (II) and $\mathrm{Fe}(\mathrm{III})$ complexes thereof (Scheme 1) and investigated their potential as anticancer drugs. It should be noted that thiomethylation is known to affect the coordination behaviour of isothiosemicarbazones toward first-row transition metals when compared to thiosemicarbazones, so that sulfur atom is not involved in binding to the metal [34]. It might also have an effect not only on the antiproliferative activity, but also on the underlying mechanism of action; therefore, one of the main aims was to address this issue in the present study. All compounds were fully characterised by analytical and spectroscopic methods. The electrochemical properties were studied by cyclic voltammetry and UV-Vis-NIR spectroelectrochemistry. Solution stabilities of $\mathbf{H L}^{\mathbf{1}}$ and $\mathbf{1}$, as well as of $\mathbf{H L}^{2}$ and $\mathbf{2}$ were monitored by UV-Vis spectroscopy. The anticancer activity of novel compounds was tested in two ovarian cancer cell lines (A2780 and A2780cis), as well as in noncancerous embryonic kidney cell line (HEK293) and their intracellular dose-dependent accumulation investigated. The ability of $\mathbf{H L}^{2}$ to quench the tyrosyl radical in hR2 RNR protein and of its $\mathrm{Fe}(\mathrm{II})$ complex to generate ROS in aqueous solution, was studied as well and compared with that of 3-AP and its Fe(II) complex. In addition, the effects of the most cytotoxic complex 2 on the key cancer cell signalling pathways were described. 
<smiles>N/C(=N/N=C/c1ncccc1N)c1ccccn1</smiles>

$\underline{\text { HL}} \underline{1}$

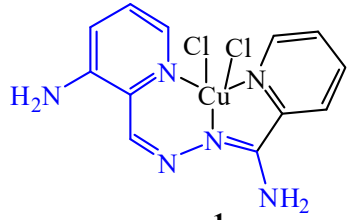

$\underline{1}$<smiles>NC(=S)N/N=C/c1ncccc1N</smiles>

3-AP

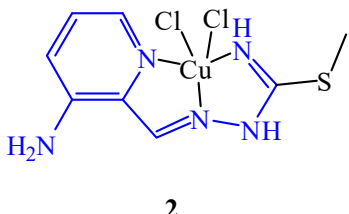<smiles>CS/C(N)=N\N=C\c1ncccc1N</smiles>

$\underline{\mathrm{HL}^{2}}$

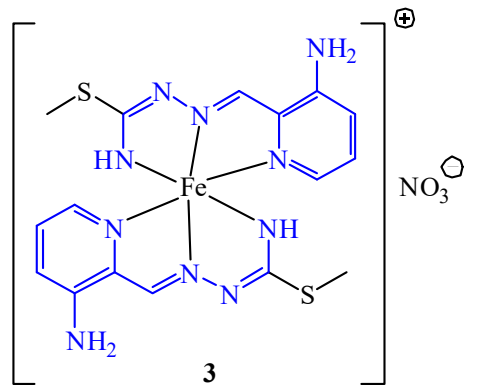

Scheme 1. Line drawings of 3-AP (triapine), carboxamidrazone $\mathbf{H L}^{\mathbf{1}}$ and isothiosemicarbazone $\mathbf{H L}^{2}$ free ligands and complexes 1-3 reported in this work. Underlined labels/numbers indicate compounds studied by X-ray crystallography.

\section{Materials and Methods}

\subsection{Chemicals}

All reagents used were received from commercial sources. 2-Cyanopyridine, $\mathrm{CuCl}_{2} \cdot 2 \mathrm{H}_{2} \mathrm{O}$ and $\mathrm{Fe}\left(\mathrm{NO}_{3}\right)_{3} \cdot 9 \mathrm{H}_{2} \mathrm{O}$ were purchased from Sigma-Aldrich. 2-Pyridinamidrazone was prepared as a white solid by the reaction of 2-cyanopyridine with excess hydrazine monohydrate as reported previously [35]. 3-N-(tert-Butyloxycarbonyl)amino-2-pyridinecarboxaldehyde [36] and S-methylisothiosemicarbazidium iodide [37] were obtained, as described in the literature. The S-methylisothiosemicarbazidium chloride was obtained from the corresponding iodide by using anion-exchange resin.

\subsubsection{3-Amino-2-pyridinecarboxaldehyde 2-pyridinamidrazone $\left(\mathbf{H L}^{\mathbf{1}}\right)$}

To a solution of 3-N-(tert-butyloxycarbonyl)amino-2-pyridinecarboxaldehyde $(0.21 \mathrm{~g}, 0.945 \mathrm{mmol})$ and 2-pyridinamidrazone $(0.13 \mathrm{~g}, 0.945 \mathrm{mmol})$ in ethanol $(8 \mathrm{~mL}) 12 \mathrm{M} \mathrm{HCl}(0.079 \mathrm{~mL}, 0.948 \mathrm{mmol})$ was added dropwise. The resulting solution was stirred at room temperature for $2 \mathrm{~h}$, and then evaporated under reduced pressure to produce an orange oil. This was crystallised in vacuo to give $\mathbf{B o c}-\mathbf{H L}^{\mathbf{1}} \cdot \mathrm{HCl}$ $\left(\mathrm{C}_{17} \mathrm{H}_{20} \mathrm{~N}_{6} \mathrm{O}_{2} \cdot \mathrm{HCl}\right.$, positive ion ESI-MS (MeCN/MeOH+1\% $\left.\mathrm{H}_{2} \mathrm{O}\right): m / z 341.16$ [Boc-HL $\left.{ }^{1}+\mathrm{H}^{+}\right)$. A part of the raw product $(0.25 \mathrm{mg}, 0.66 \mathrm{mmol})$ was suspended in ethyl acetate $(3 \mathrm{~mL})$ and a solution of $4 \mathrm{M} \mathrm{HCl} /$ EtOAc $(1 \mathrm{~mL}, 4 \mathrm{mmol})$ was added. The resulting yellow suspension was stirred at room temperature for $1 \mathrm{~h}$ and then at $45^{\circ} \mathrm{C}$ for $2 \mathrm{~h}$. The Boc-deprotection was monitored by ESI-MS (positive ion ESI-MS (MeCN/MeOH+1\% $\left.\mathrm{H}_{2} \mathrm{O}\right): m / z 241.23\left[\mathrm{HL}^{1}+\mathrm{H}\right]^{+}$). The suspension was neutralised with saturated $\mathrm{NaHCO}_{3}(\mathrm{pH} 7-8)$, then the product was extracted with ethyl acetate, washed with brine, dried over $\mathrm{Na}_{2} \mathrm{SO}_{4}$ and evaporated in vacuo to produce a yellow powder of $\mathbf{H L}^{1}\left(\mathrm{C}_{12} \mathrm{H}_{12} \mathrm{~N}_{6}\right.$, yield $0.12 \mathrm{~g}, 0.49 \mathrm{mmol}, 74 \%$ ). Crystals suitable for X-ray diffraction study were obtained in ethyl acetate/hexane mixture (1/1 v/v). Anal. Calcd for $\mathrm{C}_{12} \mathrm{H}_{12} \mathrm{~N}_{6}\left(M_{r}=240.26\right), \%$ : C, 59.98; H, 5.03; N, 34.98 . Found, \%: C, 59.78; H, 5.15; N, 34.65. Positive ion ESI-MS for $\mathrm{C}_{12} \mathrm{H}_{12} \mathrm{~N}_{6}\left(\mathrm{MeCN} / \mathrm{MeOH}+1 \% \mathrm{H}_{2} \mathrm{O}\right): m / z$ $241.23\left[\mathrm{HL}^{1}+\mathrm{H}\right]^{+}, 263.22\left[\mathrm{HL}^{1}+\mathrm{Na}\right]^{+}$, negative ion ESI-MS: $m / z 239.09\left[\mathrm{HL}^{1}-\mathrm{H}\right]^{-} .{ }^{1} \mathrm{H} \mathrm{NMR}(600 \mathrm{MHz}$, DMSO-d $\left.)_{6}\right) \delta$, ppm: $8.66\left(\mathrm{~d}, J=4.7 \mathrm{~Hz}, 1 \mathrm{H}, \mathrm{H}_{6}\right), 8.63\left(\mathrm{~s}, 1 \mathrm{H}, \mathrm{H}_{10}\right), 8.28\left(\mathrm{~d}, J=7.9 \mathrm{~Hz}, 1 \mathrm{H}, \mathrm{H}_{3}\right), 7.92$ $\left(\mathrm{td}, J=7.8,1.7 \mathrm{~Hz}, 1 \mathrm{H}, \mathrm{H}_{4}\right), 7.88\left(\mathrm{dd}, J=4.2,1.3 \mathrm{~Hz}, 1 \mathrm{H}, \mathrm{H}_{13}\right), 7.54(\mathrm{ddd}, J=7.4,4.8,1.0 \mathrm{~Hz}, 1 \mathrm{H}$, $\left.\mathrm{H}_{5}\right), 7.20\left(\mathrm{dd}, J=8.3,1.0 \mathrm{~Hz}, 1 \mathrm{H}, \mathrm{H}_{15}\right), 7.10$ (brs, 2H, $\mathrm{H}_{7}$ ), 7.09 (dd, J = 8.3, $\left.4.3 \mathrm{~Hz}, 1 \mathrm{H}, \mathrm{H}_{14}\right), 6.85$ (s, 2H, $\left.\mathrm{H}_{16}\right) .{ }^{13} \mathrm{C}$ NMR (151 MHz, DMSO-d 6$) \delta$, ppm: $160.17\left(\mathrm{C}_{10}\right), 155.03\left(\mathrm{C}_{7}\right), 150.42\left(\mathrm{C}_{2}\right), 148.42\left(\mathrm{C}_{6}\right)$, 
$144.93\left(\mathrm{C}_{16}\right), 137.09\left(\mathrm{C}_{4}\right.$ or $\left.\mathrm{C}_{13}\right), 137.01\left(\mathrm{C}_{4}\right.$ or $\left.\mathrm{C}_{13}\right), 133.90\left(\mathrm{C}_{11}\right), 125.36\left(\mathrm{C}_{5}\right), 124.31\left(\mathrm{C}_{14}\right), 121.94\left(\mathrm{C}_{15}\right)$, $121.28\left(\mathrm{C}_{3}\right) .{ }^{15} \mathrm{~N}$ NMR $\left(61 \mathrm{MHz}, \mathrm{DMSO}-\mathrm{d}_{6}\right)$ \&, ppm: $349.66\left(\mathrm{~N}_{8}\right), 321.97\left(\mathrm{~N}_{12}\right), 304.04\left(\mathrm{~N}_{1}\right), 275.94\left(\mathrm{~N}_{9}\right)$, $76.02\left(\mathrm{~N}_{7^{\prime}}\right), 71.27\left(\mathrm{~N}_{16^{\prime}}\right)$. The atom numbering for the assignment of resonances see in Scheme $\mathrm{S} 3$ in Supporting Information.

\subsection{2. $\left[\mathrm{Cu}\left(\mathrm{HL}^{1}\right) \mathrm{Cl}_{2}\right] \cdot \mathrm{H}_{2} \mathrm{O} \cdot\left(\mathbf{1} \cdot \mathrm{H}_{2} \mathrm{O}\right)$}

To a solution of $\mathbf{H L}^{\mathbf{1}}(0.100 \mathrm{~g}, 0.42 \mathrm{mmol})$ in methanol $(10 \mathrm{~mL})$ was added a solution of copper(II) chloride dihydrate $(0.062 \mathrm{~g}, 0.36 \mathrm{mmol})$ in methanol $(10 \mathrm{~mL})$. The mixture was heated to $65^{\circ} \mathrm{C}$ and left under stirring and reflux overnight. Next day the brown precipitate was filtered off and purified on preparative HPLC by using water/methanol as eluent (Figure S1). The final product was obtained as brown powder after drying in vacuo. Yield: $0.031 \mathrm{~g}, 22 \%$. Anal. Calcd for $\mathrm{C}_{12} \mathrm{H}_{12} \mathrm{Cl}_{2} \mathrm{CuN}_{6} \cdot \mathrm{H}_{2} \mathrm{O}$ $\left(M_{r}=392.73\right), \%: C, 36.69 ; \mathrm{H}, 3.59 ; \mathrm{N}, 21.39$. Found, \%: $\mathrm{C}, 37.00 ; \mathrm{H}, 3.32 ; \mathrm{N}, 21.13$. Positive ion ESI-MS for $\mathrm{C}_{12} \mathrm{H}_{12} \mathrm{Cl}_{2} \mathrm{CuN}_{6}\left(\mathrm{MeCN} / \mathrm{MeOH}+1 \% \mathrm{H}_{2} \mathrm{O}\right): \mathrm{m} / z 338.14\left[\mathrm{Cu}\left(\mathrm{HL}^{1}\right) \mathrm{Cl}\right]^{+}, 303.17\left[\mathrm{Cu}^{\mathrm{I}}\left(\mathrm{HL}^{1}\right)\right]^{+}$(Figure S2), negative ion ESI-MS: $m / z 336.02\left\{\left[\mathrm{Cu}\left(\mathrm{HL}^{1}\right) \mathrm{Cl}\right]^{+}-2 \mathrm{H}^{+}\right\}^{-}, 373.98\left[\mathrm{Cu}\left(\mathrm{HL}^{1}\right) \mathrm{Cl}_{2}-\mathrm{H}^{+}\right]^{-}$. UV-Vis (DMSO), $\lambda_{\max }, \mathrm{nm}\left(\varepsilon, \mathrm{M}^{-1} \mathrm{~cm}^{-1}\right): 714(139), 437(10,326)$. IR (ATR, selected bands, $\left.\tilde{v}_{\max }\right): 3209,3114,1636,1578$, $1538,1235,1151,1052,853,801,683,660 \mathrm{~cm}^{-1}$.

\subsubsection{3-Amino-2-pyridinecarboxaldehyde S-methylisothiosemicarbazone $\left(\mathbf{H L}^{2}\right)$}

3- $\mathrm{N}$-(tert-Butyloxycarbonyl)amino-2-pyridinecarboxaldehyde $(0.31 \mathrm{~g}, 1.4 \mathrm{mmol})$ in ethanol $(6 \mathrm{~mL})$ and S-methylisothiosemicarbazidium chloride $(0.20 \mathrm{~g}, 1.4 \mathrm{mmol})$ in water $(2 \mathrm{~mL})$ were mixed together and $12 \mathrm{M} \mathrm{HCl}(0.597 \mathrm{~mL})$ was added. The mixture was stirred at $70{ }^{\circ} \mathrm{C}$ for $3 \mathrm{~h}$. After cooling to the room temperature the solvent was removed under reduced pressure, the residue dissolved in water and neutralised with $\mathrm{NaHCO}_{3}$. Fine yellow precipitate was filtered off, washed with ethanol, diethyl ether and dried in vacuo. Yield: $0.19 \mathrm{~g}, 67 \%$. Anal. Calcd for $\mathrm{C}_{8} \mathrm{H}_{11} \mathrm{~N}_{5} \mathrm{~S}\left(M_{r}=209.27\right)$ : C, 45.91; $\mathrm{H}, 5.30$; N, 33.47; S, 15.32\%. Found, \%: C, 46.07; H, 5.28; N, 33.29; S, 15.46. Positive ion ESI-MS for $\mathrm{C}_{8} \mathrm{H}_{11} \mathrm{~N}_{5} \mathrm{~S}$ $\left(\mathrm{MeCN} / \mathrm{MeOH}+1 \% \mathrm{H}_{2} \mathrm{O}\right): m / z 210.06\left[\mathrm{HL}^{2}+\mathrm{H}\right]^{+} .{ }^{1} \mathrm{H}$ NMR (600 MHz, DMSO-d 6 , Z-isomer) $\delta$, ppm: $8.39\left(\mathrm{~s}, 1 \mathrm{H}, \mathrm{H}_{8}\right), 7.83\left(\mathrm{dd}, J=4.3,1.5 \mathrm{~Hz}, 1 \mathrm{H}, \mathrm{H}_{6}\right), 7.13\left(\mathrm{dd}, J=8.3,1.1 \mathrm{~Hz}, 1 \mathrm{H}, \mathrm{H}_{4}\right), 7.04-7.01(\mathrm{~m}, 2 \mathrm{H}$, $\left.\mathrm{H}_{5}(\mathrm{Z}-)+\mathrm{H}_{5}(\mathrm{E}-)\right), 6.90\left(\mathrm{~s}, 2 \mathrm{H}, \mathrm{H}_{13}\right), 6.67\left(\mathrm{~s}, 2 \mathrm{H}, \mathrm{H}_{7}\right), 2.39\left(\mathrm{~s}, 3 \mathrm{H}, \mathrm{H}_{12}\right) .{ }^{1} \mathrm{H}$ NMR $\left(600 \mathrm{MHz}, \mathrm{DMSO}-\mathrm{d}_{6}\right.$, E-isomer) $\delta$, ppm: $8.30\left(\mathrm{~s}, 1 \mathrm{H}, \mathrm{H}_{8}\right), 7.82\left(\mathrm{dd}, J=4.3,1.5 \mathrm{~Hz}, 1 \mathrm{H}, \mathrm{H}_{6}\right), 7.08\left(\mathrm{dd}, J=8.3,1.1 \mathrm{~Hz}, 1 \mathrm{H}, \mathrm{H}_{4}\right)$, 7.04-7.01 (m, 2H, $\left.\mathrm{H}_{5}(\mathrm{Z}-)+\mathrm{H}_{5}(E-)\right), 6.87\left(\mathrm{~s}, 2 \mathrm{H}, \mathrm{H}_{7}\right), 6.82\left(\mathrm{~s}, 2 \mathrm{H}, \mathrm{H}_{13}\right), 2.40\left(\mathrm{~s}, 3 \mathrm{H}, \mathrm{H}_{12}\right) .{ }^{13} \mathrm{C} \mathrm{NMR}$ (151 MHz, DMSO-d 6 , Z-isomer) $\delta$, ppm: $160.43\left(\mathrm{C}_{11}\right), 157.86\left(\mathrm{C}_{8}\right), 144.45\left(\mathrm{C}_{3}\right), 136.88\left(\mathrm{C}_{6}\right), 134.19\left(\mathrm{C}_{2}\right)$, $123.85\left(\mathrm{C}_{5}\right), 121.65\left(\mathrm{C}_{4}\right), 12.30\left(\mathrm{C}_{12}\right) .{ }^{13} \mathrm{C}$ NMR (151 MHz, DMSO-d 6 , E-isomer) $\delta$, ppm: $165.50\left(\mathrm{C}_{11}\right)$, $153.74\left(C_{8}\right), 144.00\left(C_{3}\right), 136.82\left(C_{6}\right), 134.70\left(C_{2}\right), 123.41\left(C_{5}\right), 121.52\left(C_{4}\right), 12.50\left(C_{12}\right) .{ }^{15} \mathrm{~N} \mathrm{NMR}(61 \mathrm{MHz}$, DMSO-d $_{6}$, Z-isomer) $\delta$, ppm: $70.93\left(\mathrm{~N}_{7}\right), 83.70\left(\mathrm{~N}_{13}\right), 267.43\left(\mathrm{~N}_{10}\right), 321.37\left(\mathrm{~N}_{1}\right), 348.34\left(\mathrm{~N}_{9}\right) .{ }^{15} \mathrm{~N}$ NMR (61 MHz, DMSO-d $\mathrm{d}_{6}$, E-isomer) $\delta$, ppm: $66.65\left(\mathrm{~N}_{7}\right), 80.46\left(\mathrm{~N}_{13}\right), 280.47\left(\mathrm{~N}_{10}\right), 319.87\left(\mathrm{~N}_{1}\right), 357.71\left(\mathrm{~N}_{9}\right)$.

\subsection{4. $\left[\mathrm{Cu}\left(\mathrm{HL}^{2}\right) \mathrm{Cl}_{2}\right](2)$}

To a solution of $\mathbf{H L}^{2}(0.050 \mathrm{~g}, 0.24 \mathrm{mmol})$ in methanol $(5 \mathrm{~mL})$ was added a solution of copper(II) chloride dihydrate $(0.041 \mathrm{~g}, 0.24 \mathrm{mmol})$ in methanol $(5 \mathrm{~mL})$. The mixture was heated to $50{ }^{\circ} \mathrm{C}$, stirred for $10 \mathrm{~min}$, and allowed to cool down to room temperature. Dark-green crystals were filtered off next day, washed with small portions of cold methanol and dried in air. Yield: $0.034 \mathrm{~g}, 41 \%$. Anal. Calcd for $\mathrm{C}_{8} \mathrm{H}_{11} \mathrm{Cl}_{2} \mathrm{CuN}_{5} \mathrm{~S}\left(M_{r}=343.72\right)$ \%: C, 27.95; H, 3.23; N, 20.37; S, 9.33. Found, \%: C, 28.13; $\mathrm{H}$, 3.30; N, 19.89; S, 8.92. Positive ion ESI-MS for $\mathrm{C}_{8} \mathrm{H}_{11} \mathrm{Cl}_{2} \mathrm{CuN}_{5} \mathrm{~S}\left(\mathrm{MeCN} / \mathrm{MeOH}+1 \% \mathrm{H}_{2} \mathrm{O}\right.$ ): $\mathrm{m} / z 271.15$ $\left[\mathrm{Cu}^{\mathrm{II}}\left(\mathrm{L}^{2}\right)\right]^{+}$; $307.13\left[\mathrm{Cu}\left(\mathrm{HL}^{2}\right) \mathrm{Cl}\right]^{+}$; negative: $m / z 304.95\left[\mathrm{Cu}\left(\mathrm{L}^{2}\right) \mathrm{Cl}-\mathrm{H}^{+}\right]^{-}$. UV-Vis $(\mathrm{MeOH}), \lambda_{\max }, \mathrm{nm}$ $\left(\varepsilon, \mathrm{M}^{-1} \mathrm{~cm}^{-1}\right)$ : 696 (122), 441 (11643), 282 (12217). IR (ATR, selected bands, $\tilde{v}_{\max }$ ): 3250, 1642, 1583, $1525,1502,1274,1217,913,877,794,643 \mathrm{~cm}^{-1}$. 


\subsection{5. $\left[\mathrm{Fe}\left(\mathrm{L}^{2}\right)_{2} \mathrm{NO}_{3}\right] \cdot 0.75 \mathrm{H}_{2} \mathrm{O}\left(3 \cdot 0.75 \mathrm{H}_{2} \mathrm{O}\right)$}

To a solution of $\mathrm{HL}^{2}(0.059 \mathrm{~g}, 0.28 \mathrm{mmol})$ in methanol $(5 \mathrm{~mL})$ was added a solution of $\mathrm{Fe}\left(\mathrm{NO}_{3}\right)_{3} \cdot 9 \mathrm{H}_{2} \mathrm{O}$ $(0.057 \mathrm{~g}, 0.14 \mathrm{mmol})$ in methanol $(5 \mathrm{~mL})$ and triethylamine $(39 \mu \mathrm{L}, 0.28 \mathrm{mmol})$. The mixture was heated to $60{ }^{\circ} \mathrm{C}$ and stirred for $20 \mathrm{~min}$. After the removal of methanol under reduced pressure, the residue was recrystallised from ethanol to give fine black microcrystals. These were filtered off, washed with ethanol, diethyl ether and dried in air. Yield: $0.033 \mathrm{~g}$, $43 \%$. Anal. Calcd for $\mathrm{C}_{16} \mathrm{H}_{20} \mathrm{FeN}_{11} \mathrm{O}_{3} \mathrm{~S}_{2} \cdot 0.75 \mathrm{H}_{2} \mathrm{O}$ $\left(M_{r}=547.9\right), \%: C, 35.07 ; \mathrm{H}, 3.96 ; \mathrm{N}, 28.12 ; \mathrm{S}, 11.71$. Found, \%: C, 35.36; H, 3.73; N, 27.90; S, 11.64. Positive ion ESI-MS for $\mathrm{C}_{16} \mathrm{H}_{20} \mathrm{FeN}_{11} \mathrm{O}_{3} \mathrm{~S}_{2}\left(\mathrm{MeCN} / \mathrm{MeOH}+1 \% \mathrm{H}_{2} \mathrm{O}\right): m / z 472.20\left[\mathrm{Fe}\left(\mathrm{L}^{2}\right)_{2}\right]^{+}$(Figure S3); negative ion: $m / z 470.03\left[\mathrm{Fe}\left(\mathrm{L}^{2}\right)_{2}-2 \mathrm{H}^{+}\right]^{-}$. UV-Vis $(\mathrm{MeOH}), \lambda_{\max }, \mathrm{nm}\left(\varepsilon, \mathrm{M}^{-1} \mathrm{~cm}^{-1}\right): 932(891), 694(590)$, 488 (12551), 428 (13956), 401sh, 301(15888), 266 (14206). IR (ATR, selected bands, $\tilde{v}_{\text {max }}$ ): 3214, 1646, $1579,1528,1466,1319,1268,1142,1057,970,849,736 \mathrm{~cm}^{-1}$.

\subsection{Physical Measurements}

Elemental analyses were carried out in a Carlo-Erba microanalyser at the Microanalytical Laboratory of the University of Vienna. Electrospray ionisation mass spectrometry (ESI MS) was carried out with amaZon speed ETD Bruker instrument (Bruker Daltonik GmbH, Bremen, Germany, $m / z$ range 0-900, ion positive/negative mode, $180^{\circ} \mathrm{C}$, heating gas $\mathrm{N}_{2}(5 \mathrm{~L} / \mathrm{min})$, Capillary $4500 \mathrm{~V}$, End Plate Offset 500 V). UV-Vis spectra were measured on Perkin Elmer UV/Vis spectrophotometer Lambda 35. IR spectra were reported on a Bucker Vertex 70 Fourier transform IR spectrometer $\left(4000-400 \mathrm{~cm}^{-1}\right)$ using the ATR technique. 1D $\left({ }^{1} \mathrm{H},{ }^{13} \mathrm{C}\right)$ and $2 \mathrm{D}\left({ }^{1} \mathrm{H}_{-}{ }^{1} \mathrm{H}\right.$ COSY, ${ }^{1} \mathrm{H}-{ }^{1} \mathrm{H}$ TOCSY, ${ }^{1} \mathrm{H}_{-}{ }^{1} \mathrm{H}$ NOESY, ${ }^{1} \mathrm{H}_{-}{ }^{13} \mathrm{C} \mathrm{HSQC}$, ${ }^{1} \mathrm{H}_{-}{ }^{13} \mathrm{C}$ HMBC, ${ }^{1} \mathrm{H}_{-}{ }^{15} \mathrm{~N}$ HSQC, ${ }^{1} \mathrm{H}_{-}-{ }^{15} \mathrm{~N}$ HMBC) NMR spectra were measured on a Bruker AV NEO 500 or AV III 600 spectrometers (Bruker BioSpin GmbH, Rheinstetten, Germany) in DMSO- $\mathrm{d}_{6}$ at $25^{\circ} \mathrm{C}$ at NMR spectroscopy Centre of the Faculty of Chemistry of the University of Vienna.

\subsection{Crystallographic Structure Determination}

X-ray diffraction measurements were performed on a Bruker X8 APEXII CCD (Karlsruhe, Germany), Bruker D8 Venture (Karlsruhe, Germany) and STOE (Darmstadt, Germany) diffractometers. Single crystals were positioned at 30, 30, 35, 40 and $40 \mathrm{~mm}$ from the detector, and 987, 360, 3319, 5298 and 527 frames were measured, each for 20,3, 10, 30 and 50 s over $0.5,0.5,0.5,1$ and $2^{\circ}$ scan width for $\mathbf{H L}^{1},\left[\mathrm{H}_{3} \mathbf{L}^{1 \mathrm{aa}}\right] \mathrm{Cl}_{2} \cdot \mathbf{2} \mathrm{H}_{2} \mathrm{O}, \mathbf{H L}^{2}, \mathbf{1}$, and $\mathbf{2}$, respectively. The data were processed using SAINT software [38]. Crystal data, data collection parameters, and structure refinement details are given in Table 1. The structures were solved by direct methods and refined by full-matrix least-squares techniques. Non-H atoms were refined with anisotropic displacement parameters. $\mathrm{H}$ atoms were inserted in calculated positions and refined with a riding model. The following computer programs and hardware were used: structure solution, SHELXS-2014 and refinement, SHELXL-2014 [39]; molecular diagrams, ORTEP [40]; computer, Intel CoreDuo. CCDC 1958520, 1958521, 1958523-1958525. 
Table 1. Crystal data and details of data collection for $\mathbf{H L}^{1},\left[\mathrm{H}_{3} \mathbf{L}^{1 \mathrm{aa}}\right] \mathrm{Cl}_{2} \cdot \mathbf{2} \mathrm{H}_{2} \mathrm{O}, \mathbf{H L}^{2},\left[\mathrm{Cu}\left(\mathrm{HL}^{1}\right) \mathrm{Cl}_{2}\right](\mathbf{1})$ and $\left[\mathrm{Cu}\left(\mathrm{HL}^{2}\right) \mathrm{Cl}_{2}\right](2)$.

\begin{tabular}{|c|c|c|c|c|c|}
\hline Compound & $\mathrm{HL}^{1}$ & {$\left[\mathrm{H}_{3} \mathrm{~L}^{1 \mathrm{a}}\right] \mathrm{Cl}_{2} \cdot 2 \mathrm{H}_{2} \mathrm{O}$} & $\mathrm{HL}^{2}$ & 1 & 2 \\
\hline empirical formula & $\mathrm{C}_{12} \mathrm{H}_{12} \mathrm{~N}_{6}$ & $\mathrm{C}_{12} \mathrm{H}_{18} \mathrm{Cl}_{2} \mathrm{~N}_{6} \mathrm{O}_{2}$ & $\mathrm{C}_{8} \mathrm{H}_{11} \mathrm{~N}_{5} \mathrm{~S}$ & $\mathrm{C}_{12} \mathrm{H}_{12} \mathrm{Cl}_{2} \mathrm{CuN}_{6}$ & $\mathrm{C}_{8} \mathrm{H}_{11} \mathrm{Cl}_{2} \mathrm{CuN}_{5} \mathrm{~S}$ \\
\hline fw & 240.28 & 349.22 & 209.28 & 374.72 & 343.72 \\
\hline space group & $\operatorname{Pna}_{1}$ & $P 2_{1} / c$ & $P 2_{1} / c$ & $P 2_{1} / c$ & $P \overline{1}$ \\
\hline$a,[\AA]$ & $16.9760(18)$ & $8.8057(3)$ & $10.9320(4)$ & $8.3933(3)$ & $8.0926(13)$ \\
\hline$b,[\AA]$ & $6.1689(7)$ & $28.3257(9)$ & $7.0723(3)$ & $11.5392(2)$ & $8.9713(15)$ \\
\hline$\alpha,\left[^{\circ}\right]$ & & & & & $78.368(7)$ \\
\hline$\beta,\left[^{\circ}\right]$ & & $109.7135(14)$ & $93.627(2)$ & $104.188(2)$ & $78.276(6)$ \\
\hline$\gamma,\left[{ }^{\circ}\right]$ & & & & & $74.508(6)$ \\
\hline$V\left[\AA^{3}\right]$ & $1146.9(2)$ & $1598.4(1)$ & $978.29(7)$ & $1418.09(7)$ & $619.15(18)$ \\
\hline$\rho_{\text {calcd }},\left[\mathrm{g} \mathrm{cm}^{-3}\right]$ & 1.392 & 1.451 & 1.421 & 1.755 & 1.844 \\
\hline cryst size, $\left[\mathrm{mm}^{3}\right]$ & $0.12 \times 0.10 \times 0.06$ & $0.35 \times 0.10 \times 0.10$ & $0.20 \times 0.18 \times 0.12$ & $0.22 \times 0.04 \times 0.04$ & $0.20 \times 0.18 \times 0.07$ \\
\hline$T[\mathrm{~K}]$ & $120(2)$ & $120(2)$ & $130(2)$ & $100(2)$ & $200(2)$ \\
\hline$\mu,\left[\mathrm{mm}^{-1}\right]$ & 0.092 & 0.422 & 0.298 & 5.662 & 2.347 \\
\hline$R_{1}^{a}$ & 0.0329 & 0.0607 & 0.0309 & 0.0358 & 0.0555 \\
\hline$w R_{2}^{b}$ & 0.0807 & 0.2349 & 0.0873 & 0.0950 & 0.2121 \\
\hline $\mathrm{GOF}^{c}$ & 1.099 & 1.180 & 1.048 & 0.958 & 1.071 \\
\hline
\end{tabular}

${ }^{a} R_{1}=\Sigma|| F_{\mathrm{o}}|-| F_{\mathrm{c}}|/ \Sigma| F_{\mathrm{o}} \mid{ }^{b} w R_{2}=\left\{\Sigma\left[w\left(F_{\mathrm{o}}{ }^{2}-{F_{\mathrm{c}}}^{2}\right)^{2}\right] / \Sigma\left[w\left(F_{\mathrm{o}}{ }^{2}\right)^{2}\right]\right\}^{1 / 2} \cdot{ }^{c} \mathrm{GOF}=\left\{\Sigma\left[w\left(F_{\mathrm{o}}{ }^{2}-F_{\mathrm{c}}{ }^{2}\right)^{2}\right] /(n-p)\right\}^{1 / 2}$, where $n$ is the number of reflections, and $p$ is the total number of parameters refined.

\subsection{Electrochemistry and Spectroelectrochemistry}

Cyclic voltammetric experiments with $0.5 \mathrm{mM}$ solutions of 1-3 in $0.1 \mathrm{M} n-\mathrm{Bu}_{4} \mathrm{NPF}_{6}$ (puriss quality from Fluka (Schwerte, Germany); dried under reduced pressure at $70{ }^{\circ} \mathrm{C}$ for $24 \mathrm{~h}$ before use) supporting electrolyte in DMSO (SeccoSolv max. $0.025 \% \mathrm{H}_{2} \mathrm{O}$, Merck) were performed under argon atmosphere using a three-electrode arrangement with a platinum disk or a glassy carbon disk working electrode (from Ionode, Australia), platinum wire as a counter electrode, and silver wire as a pseudo reference electrode. All potentials in voltammetric studies were quoted vs ferricenium/ferrocene $\left(\mathrm{Fc}^{+} / \mathrm{Fc}\right)$ redox couple. A Heka PG310USB (Lambrecht, Germany) potentiostat with a PotMaster 2.73 software package served for the potential control in voltammetric studies. In situ ultraviolet-visible-near-infrared (UV-Vis-NIR) spectroscopic and spectroelectrochemical measurements were performed on a spectrometer Avantes (Model AvaSpec-2048 $\times 14$-USB2) in $1 \mathrm{~cm}$ quartz cuvette or the spectroelectrochemical cell kit (AKSTCKIT3) with the Pt-microstructured honeycomb working electrode, purchased from Pine Research Instrumentation (Lyon, France). The cell was positioned in the CUV-UV Cuvette Holder (Ocean Optics, Ostfildern, Germany) connected to the diode-array UV-Vis-NIR spectrometer by optical fibres. UV-Vis-NIR spectra were processed using the AvaSoft 7.7 software package. Halogen and deuterium lamps were used as light sources (Avantes, Model AvaLight-DH-S-BAL, Apeldoorn, The Netherlands).

\subsection{Cell Lines and Culture Conditions}

Human ovarian carcinoma cells A2780 and A2780cis, and human embryonic kidney cells HEK293 were obtained from ATCC. A2780 and A2780cis cells were cultured in RPMI 1640 medium containing $10 \%$ fetal bovine serum (FBS). HEK293 cells were cultured in DMEM medium containing 10\% FBS. All cells were grown in tissue culture $25 \mathrm{~cm}^{2}$ flasks (BD Biosciences, Singapore) at $37^{\circ} \mathrm{C}$ in a humidified atmosphere of $95 \%$ air and $5 \% \mathrm{CO}_{2}$. All drug stock solutions were prepared in DMSO, and the final 
concentration of DMSO in the medium did not exceed $1 \%(v / v)$ at which cell viability was not inhibited. The amount of actual $\mathrm{Cu}$ concentration in the stock solutions was determined by ICP-OES.

\subsection{Inhibition of Cell Viability Assay}

The cytotoxicity of the compounds was determined by colourimetric microculture assay (MTT assay). The cells were harvested from culture flasks by trypsinisation and seeded into Cellstar 96-well microculture plates (Greiner Bio-One, Practical Mediscience Pte Ltd, Singapore, Singapore) at the seeding density of $6 \times 10^{4}$ cells per mL. After the cells were allowed to resume exponential growth for $24 \mathrm{~h}$, they were exposed to drugs at different concentrations in media for $72 \mathrm{~h}$. The drugs were diluted in complete medium at the desired concentration, and $100 \mu \mathrm{L}$ of the drug solution was added to each well and serially diluted to other wells. After exposure for $72 \mathrm{~h}$, drug solutions were replaced with $100 \mu \mathrm{L}$ of MTT in media $\left(5 \mathrm{mg} \mathrm{mL}^{-1}\right)$ and incubated for an additional $45 \mathrm{~min}$. Subsequently, the medium was aspirated, and the purple formazan crystals formed in viable cells were dissolved in $100 \mu \mathrm{L}$ of DMSO per well. Optical densities were measured at $570 \mathrm{~nm}$ with a microplate reader. The number of viable cells was expressed in terms of treated/control $(\mathrm{T} / \mathrm{C})$ values by comparison to untreated control cells, and $50 \%$ inhibitory concentrations $\left(\mathrm{IC}_{50}\right)$ were calculated from concentration-effect curves by interpolation. The evaluation was based on means from at least three independent experiments, each comprising six replicates per concentration level.

\subsection{Intracellular Accumulation}

Intracellular accumulation of $\mathbf{1}$ and $\mathbf{2}$ was determined in A2780 cells. Cells were seeded into Cellstar 6-well plates (Greiner Bio-one) at a density of $6 \times 10^{5}$ cells/well ( $2 \mathrm{~mL}$ per well). After the cells were allowed to resume exponential growth for $24 \mathrm{~h}$, they were exposed to $\mathbf{1}$ and $\mathbf{2}$ at various concentrations for $24 \mathrm{~h}$ at $37^{\circ} \mathrm{C}$. The cells were washed twice with $1 \mathrm{~mL}$ of PBS and lysed with $100 \mu \mathrm{L}$ of RIPA lysis buffer (ultrapure water, $5 \mathrm{M} \mathrm{NaCl}, 1 \mathrm{M}$ Tris- $\mathrm{HCl} \mathrm{pH}$ 8.0, $2 \%$ sodium deoxycholate, $10 \%$ SDS, IGEPAL, protease and phosphatase inhibitor) for $5-10 \mathrm{~min}$ at $4{ }^{\circ} \mathrm{C}$. The cell lysates were scraped from the wells and transferred to separate $1.5 \mathrm{~mL}$ microtubes. The supernatant was then collected after centrifugation $\left(13,000 \mathrm{rpm}, 4{ }^{\circ} \mathrm{C}\right.$ for $\left.15 \mathrm{~min}\right)$ and the total protein content of each sample was quantified via a Bradford's assay. Cell lysates were transferred to $2 \mathrm{~mL}$ glass vials and then digested with ultrapure $60 \% \mathrm{HNO}_{3}(50 \mu \mathrm{L})$ at $110{ }^{\circ} \mathrm{C}$ for $96 \mathrm{~h}$. The resulting solution was diluted to $1 \mathrm{~mL}(2-4 \%$ $(v / v) \mathrm{HNO}_{3}$ ) with ultrapure Milli-Q water, sonicated for $45 \mathrm{~min}$ and filtered through $0.45 \mu \mathrm{m}$ filters. $\mathrm{Cu}$ content of each sample was quantified by ICP-MS and expressed as per mg of protein. Re was used as an internal standard. $\mathrm{Cu}$ and Re were measured at $m / z 64$ and $m / z$ 186, respectively. Metal standards for calibration curve $(0,1,2,5,10,20,40 \mathrm{ppb})$ were prepared. All readings were performed in six replicates in He mode.

\subsection{Spectrophotometric and $\mathrm{pH}$-Potentiometric Measurements}

Agilent Carry 8454 diode array spectrophotometer was used to record the UV-Vis spectra in the interval $200-800 \mathrm{~nm}$. The path length was 1 or $2 \mathrm{~cm}$. Solution stability of ligands $\mathbf{H L}^{\mathbf{1}}$ and $\mathbf{H L}^{2}$ and their copper(II) complexes was monitored at various $\mathrm{pH}$ values by UV-Vis spectroscopy. The conditional stability constants $\left(K^{\prime}\right)$ of $\mathbf{1}$ and $\mathbf{2}$ were attempted to be calculated at pH 5.90 based on the spectral changes via the displacement reaction with ethylenediaminetetraacetic acid (EDTA) in the presence $50 \mathrm{mM}$ 2-(N-morpholino)ethanesulfonic acid (MES) and 0.1 M KCl. In this competition experiment, the samples contained $50 \mu \mathrm{M}$ complex and the concentration of EDTA was varied in the range from 0 to $422 \mu \mathrm{M}$. The reaction of $\mathbf{1}$ and $\mathbf{2}$ with glutathione (GSH) was studied at $25.0 \pm 0.1^{\circ} \mathrm{C}$ on Hewlett Packard 8452A diode array spectrophotometer using a special, tightly closed tandem cuvette (Hellma Tandem Cell, 238-QS, Altmann Analytik GmbH \& Co. KG, Munich, Germany). The reactants were held separate until the reaction was triggered. Both isolated pockets of the cuvette were completely deoxygenated by bubbling a stream of argon for $10 \mathrm{~min}$ before mixing the reactants. Spectra were recorded before and then immediately after the mixing, and changes were followed until no further 
absorbance change was observed. One of the isolated pockets contained the reducing agent (12 $\mathrm{mM}$ GSH), and the other contained the studied compound $(100 \mu \mathrm{M})$. The $\mathrm{pH}$ of all the solutions was adjusted to 7.40 by $50 \mathrm{mM}(0.1 \mathrm{M} \mathrm{KCl})$ HEPES buffer. The $\mathrm{pH}$-potentiometric titrations were performed on samples containing $\mathbf{H L}^{2}$ at $3 \mathrm{mM}$ concentration with a $\mathrm{KOH}$ solution in the presence of $0.1 \mathrm{M} \mathrm{KCl}$ at $25.0 \pm 0.1^{\circ} \mathrm{C}$. An Orion 710A pH-meter equipped with a Metrohm combined electrode (type 6.0234.100, Metrohm Inula GmbH, Vienna, Austria) and a Metrohm 665 Dosimat burette (Metrohm Inula GmbH, Vienna, Austria) were used for the $\mathrm{pH}$-metric titrations. The electrode system was calibrated to the $\mathrm{pH}=-\log \left[\mathrm{H}^{+}\right]$scale using titrations of $\mathrm{HCl}$ with $\mathrm{KOH}$ according to the method suggested by Irving et al. [41]. The average water ionisation constant $\left(\mathrm{p} K_{\mathrm{w}}\right)$ is $13.76 \pm 0.05$ in water. Argon was also passed over the solutions during the titrations. UV-Vis titration was performed for $\mathbf{H L}^{\mathbf{1}}$, which is less water-soluble compared to $\mathbf{H L}^{2}$, and the data were evaluated up to $\mathrm{pH}$ 6. Calculation of the $\mathrm{pK}$ a values was performed with the computer programs PSEQUAD $\left(\mathbf{H L}^{\mathbf{1}}\right)$ and HYPERQUAD $\left(\mathbf{H L}^{\mathbf{2}}\right)$ [42].

\subsection{Tyrosyl Radical Reduction in Human R2 RNR Protein}

The time-dependent kinetics of tyrosyl radical destruction in human $\mathrm{R} 2$ ribonucleotide reductase protein (hR2) by 3 -AP and HL $^{2}$ were measured by EPR spectroscopy at $30 \mathrm{~K}$, on a Bruker Elexsys II E540 EPR spectrometer with an Oxford Instruments ER 4112HV helium cryostat. The experimental conditions were: microwave power $3.2 \mathrm{~mW}$, modulation amplitude $5 \mathrm{G}$, modulation frequency $100 \mathrm{kHz}$, and conversion time 0.0293 s. Spectra were recorded and analysed using the Bruker Xepr software. The concentration of the tyrosyl radical was determined by double integration of EPR spectra recorded at non-saturating microwave power levels and compared with the copper standard [43]. Purified, recombinant, iron-reconstituted hR2 [44] was obtained from the Department of Biochemistry and Biophysics, Stockholm University, Sweden. The samples containing $20 \mu \mathrm{M}$ hR2 in $50 \mathrm{mM}$ Hepes buffer, pH 7.60/100 mM KCl/5\% glycerol, and $20 \mu \mathrm{M} 3-\mathrm{AP}$ or $\mathbf{H L}^{2}$ in $1 \%(v / v) \mathrm{DMSO} / \mathrm{H}_{2} \mathrm{O}$, and $2 \mathrm{mM}$ dithiothreiotol were incubated for indicated times and quickly frozen in cold isopentane. The same sample was used for repeated incubations at room temperature. The experiments were performed in duplicates.

\subsection{EPR Spin Trapping Experiments}

The generation of paramagnetic intermediates was monitored by cw-EPR spectroscopy using the EMX spectrometer (Bruker). The EPR spectra were measured with following experimental parameters: X-band, room temperature, microwave frequency, $9.431 \mathrm{GHz}$; modulation frequency, $100 \mathrm{kHz}$; field modulation amplitude, $2 \mathrm{G}$; time constant, $10 \mathrm{~ms}$; scan time, $41 \mathrm{~s}$ (5 scans). Distilled and deionised water was used for the preparation of DMSO/water solutions. The spin trapping agent 5,5-dimethyl-1-pyrroline N-oxide (DMPO; Sigma-Aldrich, Schnelldorf, Germany) was distilled prior to the application.

\subsection{Western Blotting Experiments}

The experiments were performed, as described previously [21].

\section{Results and Discussion}

\subsection{Synthesis and Characterisation of the $\mathbf{H L}^{\mathbf{1}}, \mathbf{H L}^{2}, \mathrm{Cu}(\mathrm{II})$ Complexes $\mathbf{1}$ and $\mathbf{2}$ and Fe(III) Complex 3}

HL $^{1}$ was obtained by the condensation reaction of 3-N-(tert-butyloxycarbonyl)amino-pyridine2-carboxaldehyde with 2-pyridinamidrazone in the presence of $12 \mathrm{M} \mathrm{HCl}$ in 1:1:1 molar ratio in ethanol followed by Boc-deprotection in $4 \mathrm{M} \mathrm{HCl} /$ ethyl acetate (EtOAc) (1:6) at $45^{\circ} \mathrm{C}$ in $74 \%$ yield (Scheme S1). The reaction was monitored by positive ion ESI mass spectrometry. First, the formation of Boc-HL $\mathbf{B L}^{\mathbf{1}}$ was confirmed by the presence of the peak at $m / z 341.16$ attributed to $\left[\mathrm{Boc}-\mathrm{HL}^{1}+\mathrm{H}\right]^{+}$, and then the Boc-deprotection by the presence of the peak at $m / z 241.23$ assigned to $\left[\mathrm{HL}^{1}+\mathrm{H}\right]^{+}$. It was noticed that Boc-deprotection performed under more severe conditions by prolonged boiling the Boc-HL ${ }^{1}$ 
in the presence of excess $12 \mathrm{M} \mathrm{HCl}(1: 5)$ in ethanol/water (3/1) afforded another product $\left(\mathbf{H L}^{\mathbf{1 a}}\right) \mathrm{with}^{\mathrm{ith}}$ the same molecular mass as $\mathbf{H L}^{\mathbf{1}}$ as confirmed by ESI mass spectrum (see Supporting Information (SI) for the synthesis of $\mathbf{H L}^{\mathbf{1 a}}$ and Scheme S1 for its line drawing). The formation of two different products $\mathbf{H L}^{\mathbf{1}}$ (crystallisation in ethyl acetate/hexane) and $\mathbf{H L}^{\mathbf{1 a}}$ (crystallisation from mother liquor as $\left[\mathbf{H}_{3} \mathbf{L}^{\mathbf{1 a}}\right] \mathbf{C l}_{\mathbf{2}} \cdot \mathbf{2} \mathbf{H}_{\mathbf{2}} \mathrm{O}$ ) was confirmed by single crystal $\mathrm{X}$-ray diffraction analyses (see Figure 1 and Figure S4 in SI) and multinuclear NMR spectroscopy.
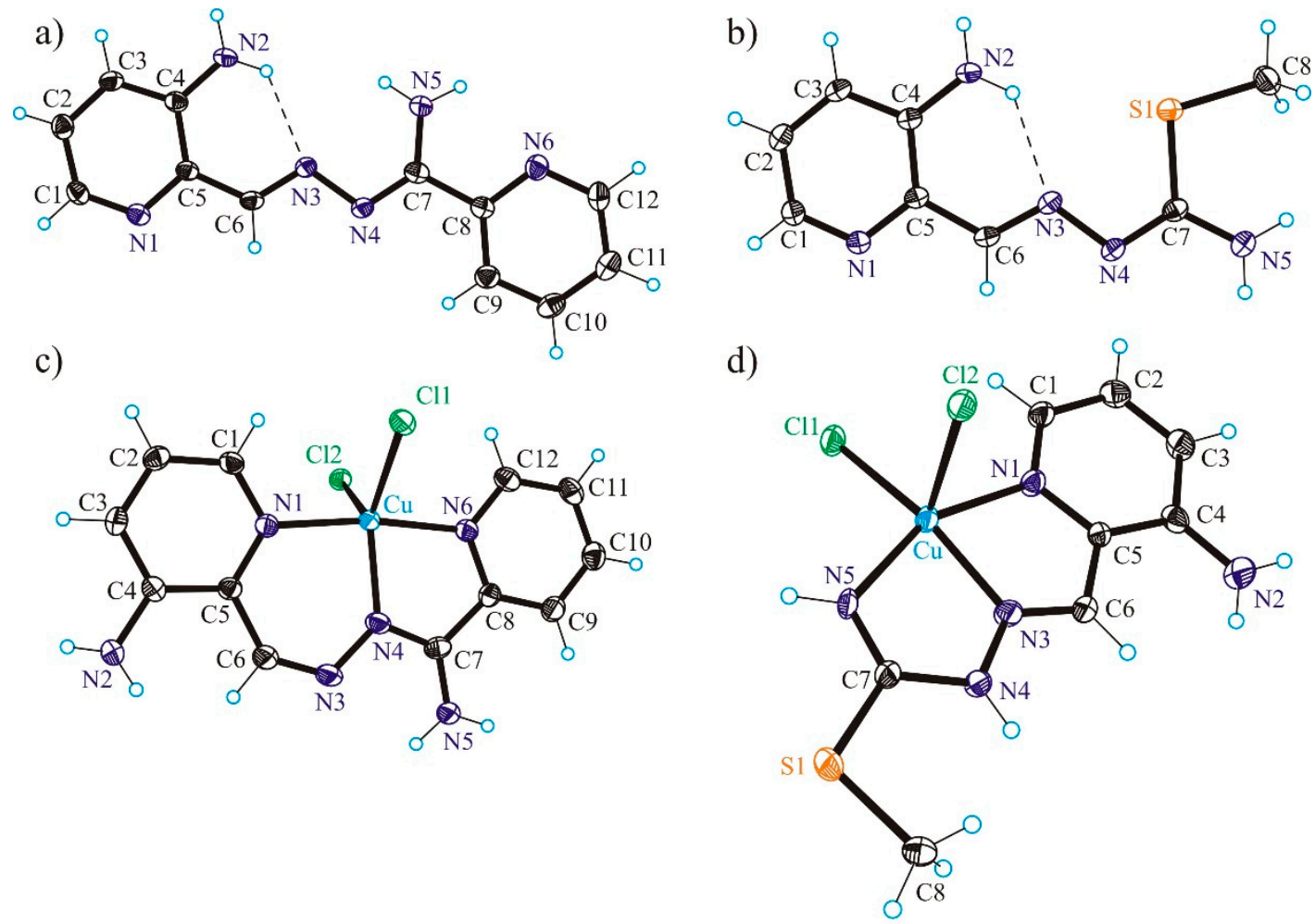

Figure 1. ORTEP views of (a) $\mathbf{H L}^{1},(\mathrm{~b}) \mathbf{H L}^{2},(\mathrm{c})\left[\mathrm{Cu}\left(\mathrm{HL}^{1}\right) \mathrm{Cl}_{2}\right](\mathbf{1})$ and (d) $\left[\mathrm{Cu}\left(\mathrm{HL}^{2}\right) \mathbf{C l}_{2}\right]$ (2). Selected bond distances $(\AA)$ and bond/torsion angles (deg) in HL $^{1}$ : C4-N2 1.350(3), C4-C5 1.422(3), C5-C6 1.455(2), C6-N3 1.290(2), N3-N4 1.4062(19), N4-C7 1.302(2), C7-N5 1.345(2), C7-C8 1.487(2), C8-N6

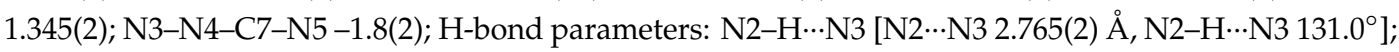
in $\mathrm{HL}^{2}$ : C4-N2 1.3514(15), C6-N3 1.2828(14), N3-N4 1.3970(12), N4-C7 1.3044(14), C7-N5 1.3471(14), C7-S 1.7643(11), S1-C8 1.8043(12); C1-N1-C5-C6 -179.31(10), N3-N4-C7-N5 -174.898(10); in 1: Cu-N1 1.997(2), Cu-N4 1.973(2), Cu-N6 2.006(2), Cu-Cl1 2.3255(7), Cu-Cl2 2.5190(6), C6-N3 1.278(4), N3-N4 1.372(3), N4-C7 1.330(3), C7-N5 1.321(3); N1-Cu-N4 91.52(8), N4-Cu-N6 80.12(8), N4-Cu-Cl1 136.54(7), N4-Cu-Cl2 111.58(6); in 2: Cu-N1 2.063(5), Cu-N3 1.960(5), Cu-N5 1.990(4), Cu-Cl1 2.2370(17), Cu-Cl2 2.5517(17), C6-N3 1.281(7), N3-N4 1.369(6), N4-C7 1.370(7), C7-N5 1.300(7); C7-S1 1.747(5), S1-C8 1.804(6), N1-Cu-N3 78.50(19), N3-Cu-N5 78.13(19), N3-Cu-Cl1 162.08(17), N3-Cu-Cl2 100.07(16), C1-N1-C5-C6 175.7(5), N3-N4-C7-N5 0.8(8).

It was envisioned that $\mathbf{H L}^{\mathbf{1}}$ may exist in two tautomeric forms $\mathbf{A}^{\mathbf{H L 1}}$ and $\mathbf{B}^{\mathrm{HL1}}$ (Scheme S2 in SI). However, the ${ }^{1} \mathrm{H}$ NMR spectrum of $\mathbf{H L}^{\mathbf{1}}$ in DMSO- $\mathrm{d}_{6}$ showed only one set of signals, which was attributed to the tautomeric form $\mathbf{A}^{\mathrm{HL1}}$. The presence of two amine groups was evidenced by two proton singlets at $6.85\left(\mathrm{H}_{16^{\prime}}\right)$ and $7.10\left(\mathrm{H}_{7^{\prime}}\right)$ ppm in the ${ }^{1} \mathrm{H}$ NMR spectrum, as well as by the N-H resonances at $71.27\left(\mathrm{~N}_{16^{\prime}}\right)$ and $76.02\left(\mathrm{~N}_{7^{\prime}}\right)$ ppm in the ${ }^{1} \mathrm{H}^{15} \mathrm{~N}$ HSQC spectrum (for atom numbering see Scheme S3 in SI).

The reaction of $\mathbf{H L}^{1}$ with $\mathrm{CuCl}_{2} \cdot 2 \mathrm{H}_{2} \mathrm{O}$ in methanol in 1:1 molar ratio under reflux afforded a brown solid that was purified by preparative HPLC to give $\mathbf{1} \cdot \mathbf{H}_{\mathbf{2}} \mathbf{O}$ (Figure S1). The positive ion ESI mass spectrum showed peaks at $m / z 338.14$ and 303.17 which could be assigned to $\left[\mathrm{Cu}^{\mathrm{II}}\left(\mathrm{HL}^{1}\right) \mathrm{Cl}^{+}\right.$and 
$\left[\mathrm{Cu}^{\mathrm{I}}\left(\mathrm{HL}^{1}\right)\right]^{+}$, respectively (Figure S2). The X-ray diffraction quality single crystals of $\mathbf{1}$ were grown in methanol. Several attempts to prepare the $\mathrm{Fe}(\mathrm{III})$ complex with $\mathbf{H L}^{\mathbf{1}}$ in a similar manner failed.

$\mathrm{HL}^{2}$ was synthesised by the reaction of 3-N-(tert-butyloxycarbonyl)amino-2-pyridinecarboxaldehyde with S-methylisothiosemicarbazidium chloride in the presence of excess hydrochloric acid followed by neutralisation of the reaction mixture with $\mathrm{NaHCO}_{3}$ in water in $67 \%$ yield. The positive ion ESI mass spectrum showed a peak at $m / z 210.06$ attributed to $\left[\mathrm{HL}^{2}+\mathrm{H}\right]^{+}$. Single crystals of $\mathbf{H L}^{2}$ were obtained from ethanol/water (3/1) mixture. The 2D NMR spectra of $\mathbf{H L}^{2}$ (in DMSO-d $\mathrm{d}_{6}$ ) contain two sets of signals in 1.6:1 intensity ratio, which were attributed to thioamide (form $\mathbf{A}^{\mathrm{HL2}}$ ) E/Z-isomers (Schemes S2 and $\mathrm{S} 4$ in SI). The E-isomer is stabilised by the intramolecular $\mathrm{N}-\mathrm{H} \cdots \mathrm{N}$ hydrogen bond (Scheme $\mathrm{S} 4$ in $\mathrm{SI}$ ). In accord with this, the proton resonance of $\mathrm{H}_{7}$ is down-field shifted to $6.87 \mathrm{ppm}$ (dominant set, $E$-isomer); $\mathrm{H}_{7}$ in the minor isomer is seen at $6.67 \mathrm{ppm}$ (Z-isomer). As for $\mathbf{H L}^{1}$, the presence of two amine groups was confirmed by two proton singlets displayed by $E$-isomer at $6.87\left(\mathrm{H}_{7}\right)$ and $6.82\left(\mathrm{H}_{13}\right)$ and Z-isomer at $6.90\left(\mathrm{H}_{13}\right)$ and $6.67\left(\mathrm{H}_{7}\right) \mathrm{ppm}$, as well as by the $\mathrm{N}-\mathrm{H}$ resonances for $E$-isomer at 66.7 $\left(\mathrm{N}_{7}\right)$ and $80.5\left(\mathrm{~N}_{13}\right)$ or for Z-isomer at $70.9\left(\mathrm{~N}_{7}\right)$ and $83.7\left(\mathrm{~N}_{13}\right)$ ppm in the ${ }^{1} \mathrm{H}^{15} \mathrm{~N}$ HSQC spectra.

The reaction of $\mathbf{H L}^{2}$ with $\mathrm{CuCl}_{2} \cdot 2 \mathrm{H}_{2} \mathrm{O}$ in methanol in a 1:1 molar ratio afforded dark-green crystals of 2 of X-ray diffraction quality. The positive ion ESI mass spectrum showed peaks at $m / z 271.15$ and 307.13 which could be assigned to $\left[\mathrm{Cu}^{\mathrm{II}}\left(\mathrm{L}^{2}\right)\right]^{+}$and $\left[\mathrm{Cu}^{\mathrm{II}}\left(\mathrm{HL}^{2}\right) \mathrm{Cl}\right]^{+}$, respectively. Black microcrystalline product $\mathbf{3} \cdot \mathbf{0 . 7 5} \mathrm{H}_{\mathbf{2}} \mathrm{O}$ was prepared from $\mathbf{H L}^{2}, \mathrm{Fe}\left(\mathrm{NO}_{3}\right)_{3} \cdot 9 \mathrm{H}_{2} \mathrm{O}$ and triethylamine in 2:1:2 molar ratio in methanol. The positive ion ESI mass spectrum showed a peak at $\mathrm{m} / \mathrm{z} 472.20$, which could be assigned to $\left[\mathrm{Fe}\left(\mathrm{L}^{2}\right)_{2}\right]^{+}$(Figure S3).

\subsection{X-ray Crystallography}

The results of X-ray diffraction studies of $\mathbf{H L}^{1},\left[\mathbf{H}_{3} \mathbf{L}^{\mathbf{1 a}}\right] \mathbf{C l}_{2} \cdot \mathbf{2} \mathrm{H}_{2} \mathrm{O}, \mathbf{H L}^{2},\left[\mathbf{C u}\left(\mathbf{H L}^{\mathbf{1}}\right) \mathbf{C l}_{2}\right](\mathbf{1})$ and $\left[\mathbf{C u}\left(\mathbf{H L}^{2}\right) \mathbf{C l}_{2}\right]$ (2) are shown in Figure 1 and Figure S4. The free ligand $\mathbf{H L}^{\mathbf{1}}$ crystallised in the orthorhombic space group $P n a 2_{1}, \mathbf{H L}^{2}$ and $\mathbf{1}$ in the monoclinic space group $P 2_{1} / c$, while $\mathbf{2}$ in the triclinic centrosymmetric space group $P \overline{1}$.

Both, $\mathbf{H L}^{1}$ and $\mathbf{H L}^{2}$ in $\mathbf{1}$ and $\mathbf{2}$ act as neutral tridentate ligands. $\mathbf{H L}^{\mathbf{1}}$ forms one six-membered and one five-membered chelate rings upon coordination to $\mathrm{Cu}(\mathrm{II})$, while $\mathbf{H L}^{2}$ forms two five-membered chelate rings. The coordination polyhedron around $\mathrm{Cu}(\mathrm{II})$ in $\mathbf{1}$ is intermediate between trigonal-bipyramidal and square-pyramidal $\left(\tau_{5}=0.58\right)$. The same distorted coordination geometry was reported previously for a closely related complex $\left[\mathrm{Cu}(\mathrm{appc}) \mathrm{Cl}_{2}\right]$ (appc $=2$-acetylpyridinepyridine-2-carboxamidrazone) $\left(\tau_{5}=0.58\right)$ [45]. The coordination geometry of copper(II) in 2 in contrast is very close to square-pyramidal $\left(\tau_{5}=0.11\right)$ [46]. The tridentate ligand $\mathbf{H L}^{2}$ is bound to $\mathrm{Cu}(\mathrm{II})$ via nitrogen atoms N1, N3 and N5. The coordination polyhedron is further completed by two chlorido co-ligands $\mathrm{Cl} 1$ and $\mathrm{Cl} 2$. The configuration adopted by the ligand in $\mathbf{2}$ differs considerably from that adopted by $\mathbf{H L}^{2}$ in the solid-state. A two-fold rotation of the pyridine ring around $\mathrm{C} 5-\mathrm{C} 6$ bond and of the isothioamide unit around $\mathrm{N} 4-\mathrm{C} 7$ bond in $\mathrm{HL}^{2}$ are required to achieve the configuration of the isothiosemicarbazone ligand in $\mathbf{2}$. As in other $\mathrm{Cu}$ (II) complexes with tridentate isothiosemicarbazones [34], the thiomethyl group is not involved in coordination to the $3 \mathrm{~d}$ transition metal atom.

\subsection{Solution Chemistry of $\mathbf{H} \mathbf{L}^{1}, \mathbf{H} \mathbf{L}^{2}$ and Their $\mathrm{Cu}(\mathrm{II})$ Complexes (1 and 2)}

The solution behaviour of $\mathrm{Cu}$ (II) complexes with triapine and other pyridine-2 carboxaldehyde thiosemicarbazones has been reported in our recent works $[19,21,47,48]$, revealing the predominant formation of $[\mathrm{CuL}]^{+}$complexes in a wide $\mathrm{pH}$ range, including the physiological $\mathrm{pH}$, where $\mathrm{L}$ is the deprotonated monoanionic ligand. The stability of this type of complex with the $\left(\mathrm{N}_{\text {pyridine, }}, \mathrm{N}, \mathrm{S}^{-}\right)$ donor set is so high that its decomposition is negligible even at low micromolar concentrations. However, the solution stability data was never reported for the carboxamidrazone and the pyridine-2-carboxaldehyde S-methylisothiosemicarbazone free ligands and their $\mathrm{Cu}$ (II) complexes. $\mathbf{H L}^{2}$ and $\mathbf{2}$ were selected for a more detailed solution study, since the aim was to reveal the solution 
stability differences between $\mathrm{Cu}(\mathrm{II})$ complexes of the isothiosemicarbazone "S-methyltriapine" $\mathbf{H L}^{2}$ with $(\mathrm{N}, \mathrm{N}, \mathrm{N})$ donor set and the thiosemicarbazone (triapine) with $(\mathrm{N}, \mathrm{N}, \mathrm{S})$ donor atoms. In addition, the solution chemical properties of $\mathbf{H L}^{\mathbf{1}}$ and $\mathbf{1}$ were also monitored by UV-Vis spectrophotometry. Firstly, proton dissociation processes of $\mathbf{H L}^{2}$ were followed by $\mathrm{pH}$-potentiometry in water (Figure S5). Notably, $\mathbf{H L}^{1}$ could not be studied by this technique, due to its limited water-solubility. Based on the recorded titration curves of $\mathbf{H L}^{2}, \mathrm{p} K_{\mathrm{a}}=4.96 \pm 0.05$ was determined, which can be attributed to the deprotonation of the pyridinium nitrogen. This value is higher than that for triapine (4.25) [48]. The hydrolytic stability of this free ligand was checked by a second titration with $\mathrm{KOH}$ following back-acidification of the initially titrated sample, and a similar $\mathrm{p} K_{\mathrm{a}}(5.05 \pm 0.08)$ was obtained. $\mathrm{p} K_{\mathrm{a}}$ values $\left(\mathrm{p} K_{1} \sim 2.4\right.$ and $\left.\mathrm{p} K_{2} \sim 3.5\right)$ for $\mathbf{H L}^{1}$ could be only estimated via spectrophotometric titrations (Figure S6), since the spectra revealed time-dependence. To further investigate the solution stability of both ligands, UV-Vis spectra were recorded under argon at physiological $\mathrm{pH}$ using HEPES buffer (Figure 2) and demonstrated significant changes with time indicating the possible decomposition of the compounds. In case of $\mathbf{H L}^{2}$ most likely the elimination of $\mathrm{CH}_{3} \mathrm{SH}$ takes place in agreement with the appearance of the characteristic mercaptan odour of the samples and it seems that this transformation has no marked effect on the $\mathrm{p} K_{\mathrm{a}}$ of the pyridinium nitrogen. The time dependence of the absorbance spectra was also followed at $\mathrm{pH} 2.2(\mathrm{HCl})$ and $9.8(\mathrm{NaOH})$, showing similar spectral changes. However, the process becomes faster with increasing $\mathrm{pH}$ (Figure S7c), while it was significantly slower in pure water at $\mathrm{pH} 6.3$ (without electrolyte and buffer components). The spectral changes of $\mathbf{H L}^{\mathbf{1}}$ (Figure S8) were reminiscent of those of $\mathbf{H L}^{2}$, although the rate of the reaction was the slowest at $\mathrm{pH}$ 7.4. In this case, the significant decrease of the absorbance band at $374-400 \mathrm{~nm}$ is most likely the consequence of the less extended conjugation system in the molecule, due to the cleavage of one of the $\mathrm{C}=\mathrm{N}$ Schiff base bonds. This type of hydrolysis is typically catalysed by acid or base. Additionally, the $\mathrm{Cu}$ (II) binding ability of both ligands was considerably diminished confirming their partial decomposition as a large difference in the spectra of samples containing free ligands kept at acidic $\mathrm{pH}$ (for 0 and $24 \mathrm{~h}$ ) prior to the addition of $\mathrm{Cu}$ (II) ions and adjusting the $\mathrm{pH}$ to 7.4 (Figure S9). Although the spectral changes are relatively slow in all cases based on these findings, the complete wide $\mathrm{pH}$ range solution equilibrium studies could not be performed.

(a)

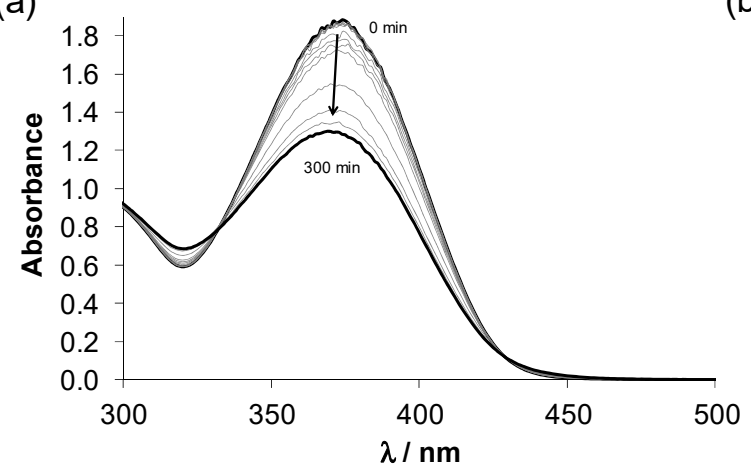

(b)

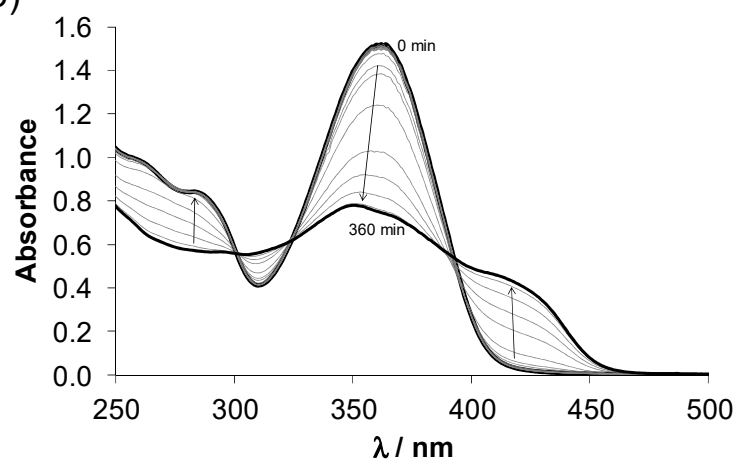

Figure 2. Time-dependent $\mathrm{UV}$-Vis spectra of $(\mathbf{a}) \mathbf{H L}^{1}$ and $(\mathbf{b}) \mathbf{H L}^{2}$ at physiological $\mathrm{pH}\left\{c_{\mathrm{L}}=100 \mu \mathrm{M}\right.$; $\mathrm{pH}=7.40$ (20 mM HEPES); $\mathrm{T}=298 \mathrm{~K} ; \mathrm{I}=0.10 \mathrm{M}(\mathrm{KCl}) ; \ell=1.0 \mathrm{~cm} ; 1 \%(v / v) \mathrm{DMSO}$.

The solution stability of $\mathbf{1}$ and $\mathbf{2}$ was also investigated, and time-dependent UV-Vis spectra recorded at $\mathrm{pH}$ 2, 7.4 and 10 (Figure S10) demonstrated only minor spectral changes, indicating that the complexes are more robust at physiological $\mathrm{pH}$ than their respective ligands.

Next, the thermodynamic stability of complexes 1 and $\mathbf{2}$ was investigated by competition reactions with EDTA at pH 5.9 (Figure 3 for 2). This $\mathrm{pH}$ was chosen as comparable conditional stability constants are available for analogous complexes. Representative UV-Vis spectra are shown in the wavelength range where only 2 and the free ligand absorb light. High excess of EDTA was needed to achieve measurable ligand replacement, and $\log K^{\prime}{ }_{5.9}=7.38 \pm 0.02$ as conditional stability constant for 2 was 
obtained, and in case of $1 \log K_{5.9}^{\prime}=8.20 \pm 0.02$ was determined. These constants are lower than that of triapine (12.88), ref. [48] implying the weaker $\mathrm{Cu}$ (II) binding ability of both $\mathbf{H L}^{\mathbf{1}}$ and $\mathbf{H L}^{2}$ compared to the pyridine-2-carboxaldehyde thiosemicarbazones.

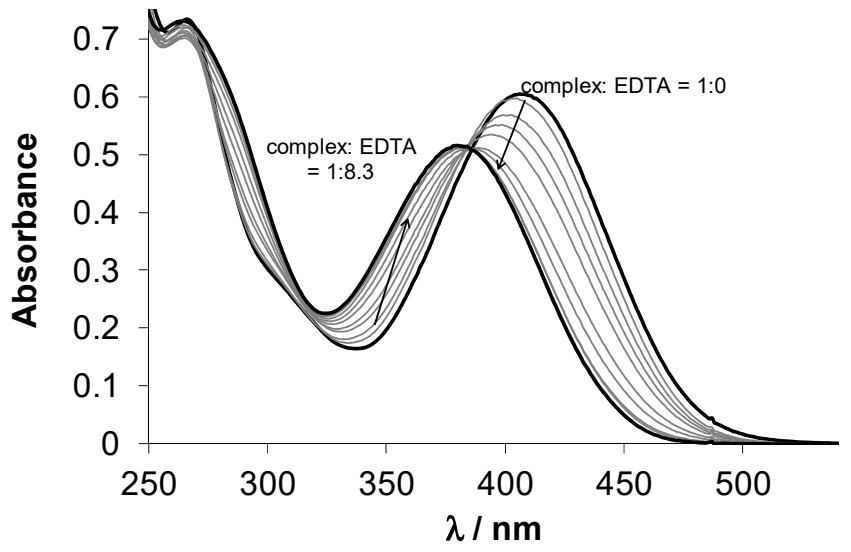

Figure 3. UV-Vis spectra of 2 in the presence of EDTA at various concentrations, and the numbers show the complex-to-EDTA ratios $\left\{\mathrm{c}_{2}=50 \mu \mathrm{M} ; \mathrm{c}_{\mathrm{EDTA}}=0-422 \mu \mathrm{M} ; \mathrm{pH}=5.90\right.$ (50 mM MES); $\mathrm{T}=298 \mathrm{~K}$; $\mathrm{I}=0.10 \mathrm{M}(\mathrm{KCl}) ; \ell=1.0 \mathrm{~cm} ; 1 \% \mathrm{DMSO}$.

\subsection{Cytotoxicity}

Complexes 1-3 were tested for antiproliferative activity against two cancer cell lines-ovarian carcinoma A2780 and its cisplatin-resistant analogue A2780cis, as well as noncancerous human embryonic kidney cell line HEK293. Their cytotoxicity, reflected by 50\% inhibitory concentration $\left(\mathrm{IC}_{50}\right)$ values, was compared to that of triapine, cisplatin and respective free ligands (Table 2 and Figure S11). The differences in the cytotoxicity between cisplatin-sensitive and cisplatin-resistant cell lines are represented by resistance factors (RF). The selectivity to cancer cells over healthy noncancerous cells is represented by the selectivity factor (SF).

Table 2. Cytotoxicity of $\mathbf{H L}^{\mathbf{1}}$ and $\mathbf{H L}^{2}$, $\mathrm{Cu}(\mathrm{II})$ complexes $\mathbf{1}$ and $\mathbf{2}$, and $\mathrm{Fe}(\mathrm{III})$ complex 3.

\begin{tabular}{|c|c|c|c|c|c|c|}
\hline \multirow[t]{2}{*}{ Compound } & \multicolumn{5}{|c|}{$\mathrm{IC}_{50}[\mu \mathrm{M}]^{a}$} & \multirow{2}{*}{$\begin{array}{c}\text { Cellular } \\
\begin{array}{c}\text { Accumulation } \\
\end{array} \text {, } \\
\text { nmol Cu/mg Protein } \\
\text { A2780 }\end{array}$} \\
\hline & A2780 & A2780cis & $\mathrm{RF}^{b}$ & HEK293 & $\mathrm{SF}^{c}$ & \\
\hline $\mathrm{HL}^{1}$ & $242 \pm 84$ & $221 \pm 79$ & 0.9 & $253 \pm 39$ & 1.0 & - \\
\hline $\mathrm{HL}^{2}$ & $202 \pm 49$ & $211 \pm 8$ & 1.0 & $187 \pm 24$ & 0.9 & - \\
\hline 1 & $17 \pm 2$ & $15 \pm 3$ & 0.9 & $28 \pm 2$ & 1.6 & $0.76 \pm 0.10$ \\
\hline 2 & $1.4 \pm 0.2$ & $0.92 \pm 0.11$ & 0.7 & $1.5 \pm 0.2$ & 1.1 & $0.64 \pm 0.18$ \\
\hline 3 & $41 \pm 12$ & $36 \pm 8$ & 0.9 & $48 \pm 9$ & 1.2 & - \\
\hline Triapine $^{e}$ & $0.67 \pm 0.22$ & $1.1 \pm 0.1$ & 1.6 & $0.39 \pm 0.05$ & 0.6 & - \\
\hline Cisplatin $^{e}$ & $0.44 \pm 0.13$ & $4.6 \pm 0.3$ & 10.5 & n.d. $f$ & - & - \\
\hline $\mathrm{CuCl}_{2} g$ & $83 \pm 12$ & $82 \pm 3$ & 1.0 & $187 \pm 37$ & 2.3 & $0.64 \pm 0.19$ \\
\hline
\end{tabular}

${ }^{a} 50 \%$ inhibitory concentrations $\left(\mathrm{IC}_{50}\right)$ in human ovarian carcinoma cell lines $\mathrm{A} 2780$ and $\mathrm{A} 2780$ cisR and human embryonic kidney cell line HEK293, determined using the MTT assay after $72 \mathrm{~h}$ exposure (Figure S11). Values are means \pm standard error of mean (SEM) obtained from at least three independent experiments, ${ }^{b}$ Resistance Factor $(\mathrm{RF})$ is determined as $\mathrm{IC}_{50}$ (A2780cisR) $/ \mathrm{IC}_{50}$ (A2780), ${ }^{c}$ Selectivity Factor (SF) is determined as $\mathrm{IC}_{50}$ (HEK293)/ $/ \mathrm{IC}_{50}$ (A2780), ${ }^{d}$ Cellular accumulation in A2780 cells, determined by Inductively Coupled Plasma Mass Spectrometry (ICP-MS) after $24 \mathrm{~h}$ exposure at concentrations, corresponding to their $0.3 \mathrm{IC}_{50}$ values. Values are means $\pm \mathrm{SEMs}$ obtained

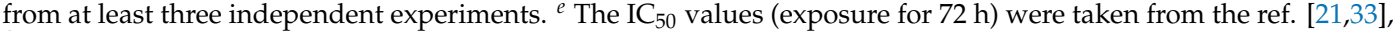
${ }^{f}$ n.d.- - not determined, ${ }^{8}$ The $\mathrm{IC}_{50}$ values were taken from ref. [33].

From Table 2, it is seen that the free ligands $\mathbf{H L}^{\mathbf{1}}$ and $\mathbf{H L}^{\mathbf{2}}$ were only marginally cytotoxic, and that their coordination to $\mathrm{Cu}(\mathrm{II})$ or $\mathrm{Fe}(\mathrm{III})$ resulted in a significant improvement of cytotoxicity, 14- and 
144-fold change for $\mathrm{Cu}$ (II) complexes 1 and 2, respectively, and nearly 5-fold increase for $\mathrm{Fe}(\mathrm{III})$ complex 3. Complex 2 was more active than triapine and cisplatin in cisplatin-resistant A2780cis cell line. In general, all compounds were similarly cytotoxic in both A2780 and A2780cis cells, which is reflected by their low RFs. Unfortunately, these compounds also demonstrated comparable toxicity in noncancerous HEK293 cells, similar to triapine and other previously reported thiosemicarbazones [21].

\section{Investigation of Mechanism of Action}

\subsection{Intracellular Accumulation}

It is known that $\mathrm{CuCl}_{2}$ salt displays anticancer activity in a range of cancer cells lines, which may be attributed to intracellular $\mathrm{Cu}$ overload which leads to ROS production, and altered cancer cell signalling $[49,50]$. However, despite the disruption of the natural homeostasis of this endogenous metal ion, the cytotoxicity of $\mathrm{CuCl}_{2}$ is very limited and manifested only at high micromolar concentrations. This is related to the hydrophilic nature of the inorganic salt, which prevents its efficient uptake by the cells. Since both $\mathbf{H L}^{1}$ and $\mathbf{H L}^{2}$ did not show any reasonable anticancer activity, it was anticipated that the improved cytotoxicity of the metal complexes was directly dependent on the metal centre. In order to compare the intracellular $\mathrm{Cu}$ accumulation between $\mathbf{1}, 2$ and $\mathrm{CuCl}_{2}, \mathrm{Cu}$ content in $\mathrm{A} 2780$ cells treated with these compounds (using $0.3 \times \mathrm{IC}_{50}$ concentration) was measured by ICP-MS (Table 2 and Figure 4 ). Cellular accumulation of the drugs depends on the cell membrane permeability and is known to increase when cellular membranes are compromised. Therefore, cells were treated with the non-toxic equipotent concentrations of the drugs with respect to their killing potential. In agreement with the initial hypothesis, both complexes demonstrated similar $\mathrm{Cu}$ accumulation as $\mathrm{CuCl}_{2}(0.64-0.76 \mathrm{nmol}$ $\mathrm{Cu} / \mathrm{mg}$ protein). Similarly, for $\mathrm{IC}_{50}$ concentrations, complexes $\mathbf{1}$ and $\mathbf{2}$ also demonstrated non-significant differences in $\mathrm{Cu}$ accumulation $(1.1 \pm 0.3$ and $0.76 \pm 0.17 \mathrm{nmol} \mathrm{Cu} / \mathrm{mg}$ protein for 1 and 2, respectively). This result indicates that despite significant differences in the cytotoxicity of complexes $\mathbf{1}, \mathbf{2}$ and $\mathrm{CuCl}_{2}$, the active $\mathrm{Cu}$ concentration in drug-treated cancer cells is similar for all three compounds, suggesting that cytotoxicity may be determined by the efficacy of intracellular delivery of $\mathrm{Cu}$ ions. However, it should be emphasised that almost identical $\mathrm{Cu}$ concentration was achieved when the concentration of 2 was ca. 12, and 60 times lower than the concentrations of $\mathbf{1}$, and $\mathrm{CuCl}_{2}$, respectively. The improved cytotoxicity of $\mathbf{2}$ may be related to a more efficient intracellular delivery or a less efficient cellular efflux.

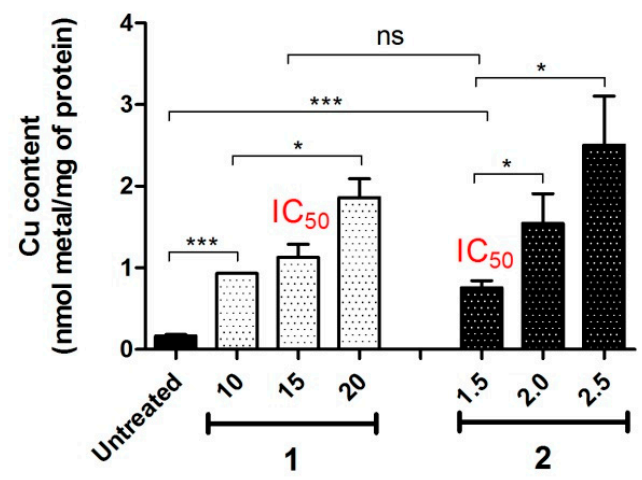

Figure 4. Intracellular $\mathrm{Cu}$ accumulation in A2780 cells. A2780 cells were treated with $\mathrm{Cu}(\mathrm{II})$ complexes 1 and 2 at $37^{\circ} \mathrm{C}$ for $24 \mathrm{~h}$ at indicated concentrations $(\mu \mathrm{M})$, and $\mathrm{Cu}$ content was measured by ICP-MS. Statistical analysis was performed by two-tailed T-test using GraphPad Prism software (GraphPad Software Inc., CA) with $p<0.05$ considered as significant $\left({ }^{*} p<0.05,{ }^{* * *} p<0.001\right)$.

\subsection{Electrochemistry}

Both, $\mathrm{Cu}$ and $\mathrm{Fe}$ are redox-active metals, which are essential for the normal cellular function, and their overload triggers the integrative cellular response, including oxidative and proteostatic stress. Since the role of the metal ion in the anticancer activity of complexes $\mathbf{1}$ and $\mathbf{2}$ was evident 
(see Table 2), complexes 1-3 were investigated for their ability to release metal ions within the biologically accessible window, which may further lead to the induction of cellular stress. To investigate the redox properties of 1-3, a detailed electrochemical study was performed by cyclic voltammetry, as well as UV-Vis-spectroelectrochemistry.

The cyclic voltammogram of $\mathbf{1}$ in $\mathrm{DMSO} / n-\mathrm{Bu}_{4} \mathrm{NPF}_{6}$ at $\mathrm{Pt}$ working electrode showed one irreversible reduction peak with cathodic peak potential $E_{\mathrm{pc}}=-0.76 \mathrm{~V} \mathrm{vs} \mathrm{Fc}^{+} / \mathrm{Fc}^{0}$ (Figure $5 \mathrm{a}$ ). The first irreversible reduction step can be attributed to the $\mathrm{Cu}(\mathrm{II}) \rightarrow \mathrm{Cu}(\mathrm{I})$ process, followed by ligand release from the unstable $\mathrm{Cu}(\mathrm{I}) \mathrm{L}$ complex. Similar to $\mathbf{1}$, complex 2 decomposed upon reduction; however, even more intricate redox behaviour was observed with two irreversible cathodic waves at $E_{\mathrm{pc}}{ }^{1}=-0.67 \mathrm{~V}$ and $E_{\mathrm{pc}}{ }^{2}=-1.05 \mathrm{~V} \mathrm{vs} \mathrm{Fc}^{+} / \mathrm{Fc}^{0}$ (Figure $5 \mathrm{~b}$ ). To further explore the chemical processes occurring at the first reduction step of 2, the in situ spectroelectrochemical UV-Vis and cyclic voltammetric experiments were carried out under an argon atmosphere in a special thin layer spectroelectrochemical cell with a microstructured honeycomb working electrode. The UV-Vis spectra measured upon cathodic reduction of 2 revealed a new optical band at $373 \mathrm{~nm}$ in the region of the first reduction peak, as well as a decrease of the intensity of the two bands at 284 and $448 \mathrm{~nm}$ (Figure 6a). Upon scan reversal, the product that was formed upon reduction of $\mathrm{Cu}(\mathrm{II})$ to $\mathrm{Cu}(\mathrm{I})$ was not reoxidised back to the initial state (Figure 6b). This unambiguously indicates that $\mathrm{Cu}(\mathrm{I})$ species were not stable and irreversibly decomposed with the full or partial ligand release. On the contrary, ferric complex 3 exhibited different redox behaviour with almost reversible electrochemical reduction with the first reduction event at $E_{1 / 2}=-0.81 \mathrm{~V} \mathrm{vs} \mathrm{Fc}^{+} / \mathrm{Fc}$ (Figure 5c).
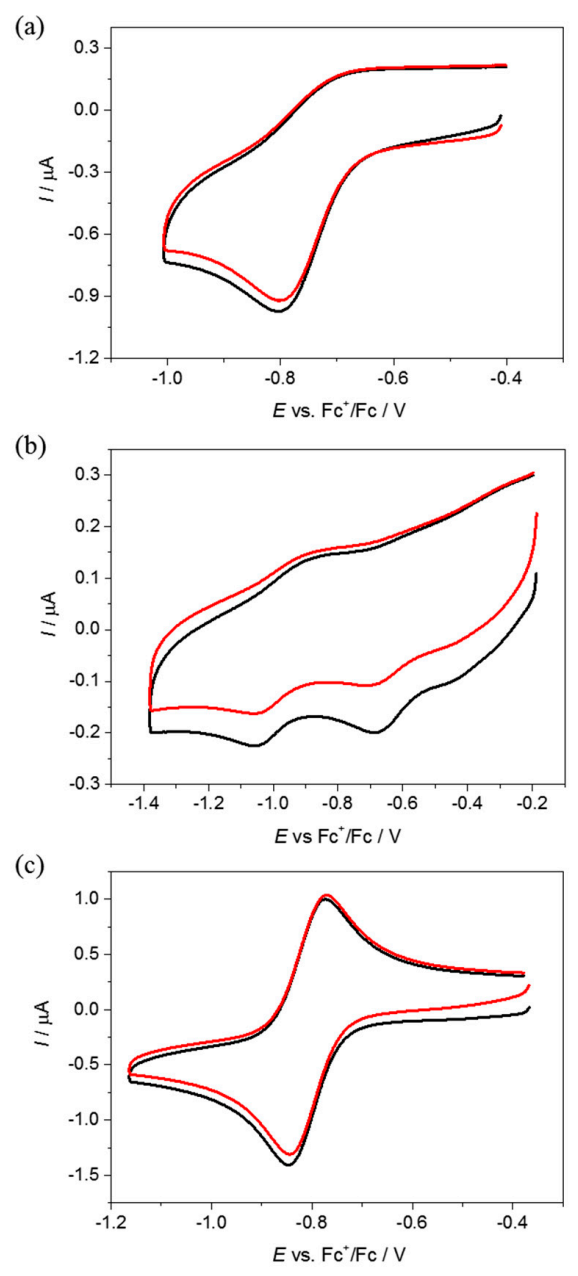

Figure 5. Cyclic voltammograms of $0.5 \mathrm{mM}(\mathbf{a})$ of $\mathbf{1}$, (b) 2 and (c) 3 in $\mathrm{DMSO} / n-\mathrm{Bu}_{4} \mathrm{NPF}_{6}$ at a scan rate of $100 \mathrm{mV} \mathrm{s}^{-1}$ (black traces represent the first scan, while red traces the second scan). 
(a)
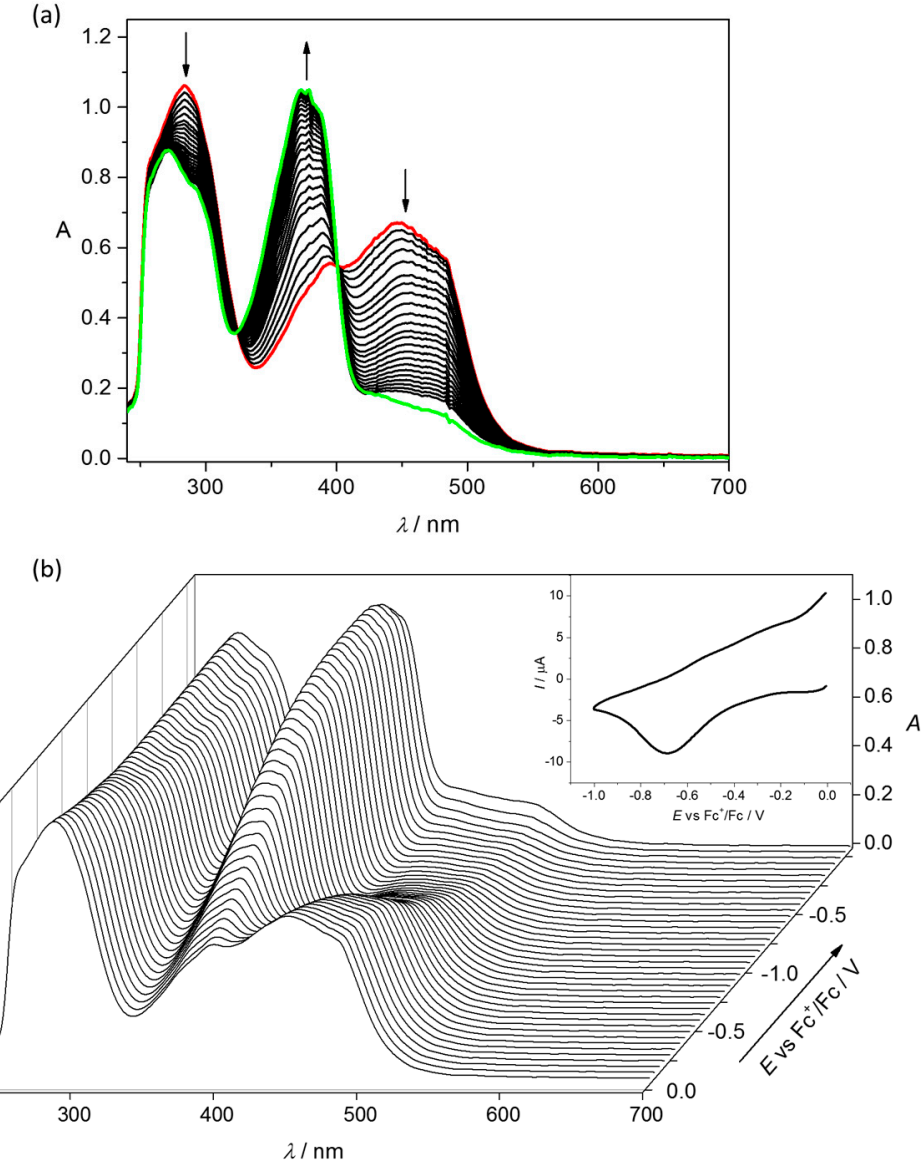

Figure 6. In situ UV-Vis spectroelectrochemistry for 2 in $\mathrm{DMSO} / n-\mathrm{Bu}_{4} \mathrm{NPF}_{6}$ (scan rate of $10 \mathrm{mV} \mathrm{s}^{-1}$, Pt-microstructured honeycomb working electrode): (a) Evolution of UV-Vis spectra in 2D projection in the forward scan; (b) UV-Vis spectra detected simultaneously upon the cyclic voltammetric scan (Inset-respective cyclic voltammogram).

\subsection{Intracellular Release of Metal Ions}

Cancer cells are characterised by the high levels of GSH, the low molecular mass antioxidant tripeptide, and a reducing intracellular environment. Following the observations from the cyclic voltammetry experiments, it was investigated whether complexes 1 and $\mathbf{2}$ could release $\mathrm{Cu}$ ions in the presence of GSH. The reduction of $\mathbf{1}$ and $\mathbf{2}$ by GSH was followed by UV-Vis spectrophotometry under the anaerobic condition at $\mathrm{pH}$ 7.4. A tightly closed tandem cuvette was used, containing $\mathrm{Cu}$ complexes in one of the pockets, and 120 equiv. GSH in the other one. After triggering the reaction, the first recorded spectrum (10 s) revealed significant spectral changes, due to the fairly fast reduction of the complexes (Figure S12), similar to the spectroelectrochemical UV-Vis behaviour summarised in Figure 6a. The reaction was found to be extremely fast for $\mathbf{1}$ and the final spectrum corresponded to that of the free ligand $\mathbf{H L}^{\mathbf{1}}$. However, the generated final spectrum in case of $\mathbf{2}$ does not correspond to the ligand $\mathbf{H L}^{2}$, the $\lambda_{\max }(388 \mathrm{~nm})$ is somewhat shifted to the higher wavelengths (Figure S8a, $\lambda_{\max }$ of $\mathrm{HL}^{2}$ : $362 \mathrm{~nm}$ under the same condition). When passing oxygen through the solutions of the reduced complexes, there were no significant spectral changes observed, and the initial spectra could not be recovered.

Upon cathodic reduction of 3 in $\mathrm{DMSO} / n-\mathrm{Bu}_{4} \mathrm{NPF}_{6}$ at the first electron transfer new absorption bands at 649, 395 and $289 \mathrm{~nm}$ arise with a simultaneous decrease of the initial optical band at $500 \mathrm{~nm}$ via isosbestic points at 550, 444, 274 and $300 \mathrm{~nm}$ (Figure 7a). Additionally, upon voltammetric reverse scan nearly full recovery of the initial optical bands was observed, attesting the chemical reversibility 
of the cathodic reduction even at low scan rates (Figure $7 \mathrm{~b}$ ). These results are comparable with those reported for other Fe(III)-TSC complexes [27,51].

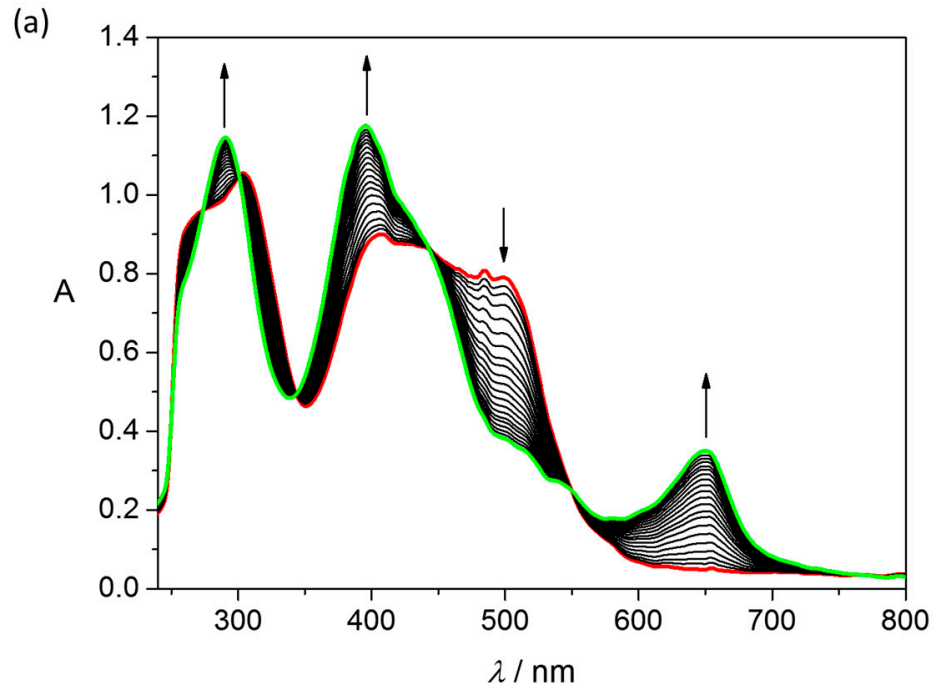

(b)

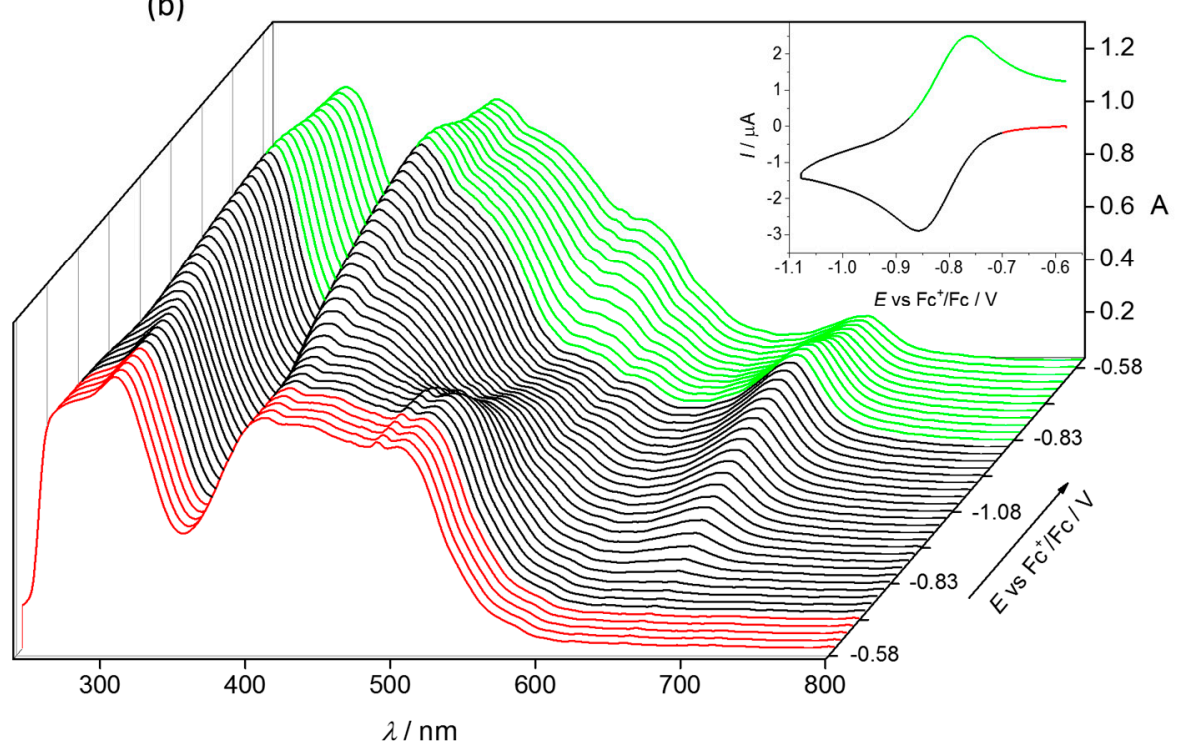

Figure 7. Spectroelectrochemistry of 3 in $n-\mathrm{Bu}_{4} \mathrm{NPF}_{6} / \mathrm{DMSO}$ in the region of the first cathodic peak. (a) UV-Vis spectra detected simultaneously during the in situ reduction (Pt-microstructured honeycomb working electrode, scan rate $\mathrm{v}=10 \mathrm{mV} \mathrm{s}^{-1}$ ); (b) potential dependence of UV-Vis spectra (Inset-respective cyclic voltammogram with the colour-highlighted potential region, where spectra were recorded).

Based on the results of the spectroelectrochemical experiments, it was concluded that complexes 1-3 can release metal ions in the reducing cellular environment. However, even minor changes in the structure of the complexes significantly affected chemical transformations accompanying their reduction. The reduction of complex $\mathbf{1}$ resulted in the irreversible release of inactive ligand $\mathbf{H L}^{\mathbf{1}}$ and $\mathbf{C u}$ ions; therefore, its anticancer activity may be fully attributable to the $\mathrm{Cu}$ centre. Similarly, the reduction of complex 2 also resulted in an irreversible release of $\mathrm{Cu}$ ions; however, it was accompanied by the formation of a new organic species, different from $\mathbf{H L}^{2}$, which has not been identified. On the contrary, Fe complex 3 demonstrated reversible redox cycling, which commonly leads to sustainable cellular ROS production. 
Ex vivo ROS detection. To further investigate the redox processes occurring upon reversible reduction of complex 3, we performed EPR spin trapping experiments with $\left[\mathrm{Fe}^{\mathrm{II}}\left(\mathrm{L}^{2}\right)_{2}\right]$, in comparison with the $\mathrm{Fe}^{\mathrm{II}}$-triapine complex, $\mathrm{Fe}^{\mathrm{II}}\left(\mathbf{3}-\mathrm{APH}_{-1}\right)_{2}$, ref. [10] using DMPO as the spin trapping agent (Figures S13 and S14). The reaction mixture contained $0.45 \mathrm{mM}$ free ligand in $1 \%(v / v) \mathrm{DMSO} / \mathrm{H}_{2} \mathrm{O}$, $0.04 \mathrm{M}$ DMPO, freshly prepared aqueous solution of $\mathrm{FeSO}_{4}(0.22 \mathrm{mM})$ to form bis-ligand complexes, and $0.1 \mathrm{M} \mathrm{H}_{2} \mathrm{O}_{2}$, and the EPR spectra were recorded immediately. As shown in Figure S13, for both, $\left[\mathrm{Fe}^{\mathrm{II}}\left(3-\mathrm{APH}_{-1}\right)_{2}\right]$ and $\left[\mathrm{Fe}^{\mathrm{II}}\left(\mathrm{L}^{2}\right)_{2}\right]$ the rapid formation of the DMPO-OH・ spin-adducts with similar yields was confirmed in both cases. No production of ROS was observed for free ligands (3-AP and $\mathbf{H L}^{2}$ ), confirming the crucial role of Fe for ROS generation. More stable adducts were observed in $5 \%(v / v) \mathrm{DMSO} / \mathrm{H}_{2} \mathrm{O}$ system where the carbon centred spin-adducts dominated, as previously reported for dithiothreitol-reduced [ $\mathrm{Fe}^{\mathrm{II}}\left(3-\mathrm{APH}_{-1}\right)_{2}$ ] in the presence of DMPO [11]. In this case, DMSO acted as a HO• scavenger generating methyl radicals which are trapped by DMPO. The EPR spin trapping experiments suggest that reversible reduction of complex 3 led to the production of the Fenton-generated $\mathrm{OH} \bullet$ radicals, similar to the $\mathrm{Fe}^{\mathrm{II}}$-triapine complex, which may be responsible for cancer cell death.

\section{4. $h R 2$ RNR Inhibition by $\mathbf{H L}^{2}$}

The results presented thus far, regarding the lead compound, complex 2, showed that $\mathbf{H L}^{2}$ coordination to $\mathrm{Cu}$ (II) resulted in a significant improvement of its cytotoxicity, which is most likely determined by its efficient intracellular delivery of copper ions. To further confirm that the cytotoxicity of $\mathbf{2}$ is determined by the ligand's ability to serve as a copper delivery vehicle, further experiments with the ligand, $\mathbf{H L}^{2}$, were performed. Namely, since $\mathbf{H L}^{2}$ is structurally related to 3-AP, which has been shown to be a potent hR2 RNR inhibitor, tyrosyl radical destruction in hR2 by $\mathbf{H L}^{2}$ was measured by EPR spectroscopy at $30 \mathrm{~K}$ and compared to that by 3-AP. 3-AP efficiently inhibits mammalian R2 RNR in the presence of an external reductant (GSH or DTT), and as reported recently [21], several studies have shown that it is the formed $\left[\mathrm{Fe}^{\mathrm{II}}\left(3-\mathbf{A P H}_{-1}\right)_{2}\right]$ species that is responsible for the R2-specific RNR inhibitory effect of 3-AP [9-11,52,53].

When equimolar amounts of protein and ligand were incubated in the presence of DTT, $50 \%$ tyrosyl radical reduction was observed after $45 \mathrm{~s}$ with $3-\mathrm{AP}$, and $5 \mathrm{~min}$ with $\mathbf{H L}^{2}$ (Figure 8). Furthermore, 3-AP reduced 100\% radical after approximately $3 \mathrm{~min}$, which is in agreement with previously published results for mouse R2 RNR [10]. However, in the same experimental conditions, $\mathbf{H L}^{2}$ was not able to reduce $100 \%$ radical in hR2 even after $10 \mathrm{~min}$. These results indicate that $\mathrm{HL}^{2}$ is not as efficient $\mathrm{hR} 2$ inhibitor as 3-AP, in agreement with its marginal cytotoxicity, and provides further evidence about its role as an intracellular copper delivery vehicle, contributing to the cytotoxic activity of complex 2.

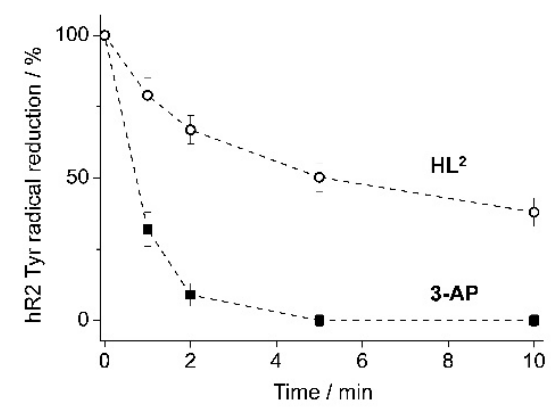

Figure 8. Tyrosyl radical reduction in human $\mathrm{R} 2 \mathrm{RNR}$ protein by $3-\mathrm{AP}$ and $\mathbf{H L}^{2}$ in the presence of an external reductant. The samples contained $20 \mu \mathrm{M} \mathrm{hR} 2$ in $50 \mathrm{mM}$ Hepes buffer, $\mathrm{pH} 7.60 / 100 \mathrm{mM} \mathrm{KCl} / 5 \%$ glycerol, and $20 \mu \mathrm{M} 3-\mathrm{AP}_{\text {or }} \mathrm{HL}^{2}$ in $1 \%(v / v) \mathrm{DMSO} / \mathrm{H}_{2} \mathrm{O}$, and $2 \mathrm{mM}$ dithiothreiotol (DTT). Error bars are the standard deviation from two independent experiments. 


\subsection{The Effects of $\mathrm{Cu}$ Overload on Cancer Cell Signalling}

While ROS-inducing properties of $\mathrm{Cu}$ ions, as well as $\mathrm{Cu}$ complexes, have been exhaustively studied, their effects on cancer signalling cascades have been largely overlooked [54]. Recently, the microarray analysis of $\mathrm{Cu}$-overloaded colon cancer cells revealed the disruption of genes involved in unfolded protein response (UPR), proteasomal degradation and autophagy-the major pro-survival cellular responses [49]. However, prolonged $\mathrm{Cu}$ treatment led to the activation of caspase-dependent and -independent modes of cell death [49]. Several Cu-thiosemicarbazone complexes were also shown to induce UPR, autophagy and antioxidant defence $[21,55,56]$. Therefore, the effects of the most active complex 2 on the expression of pro-apoptotic UPR marker CHOP were determined, as well as the antioxidant defence marker Nrf2 (Figure 9). When A2780 cells were treated with increasing concentrations of 2 for $24 \mathrm{~h}$, the increase of both, Nrf2 and CHOP was observed even at low concentrations $(1 \mu \mathrm{M})$. In addition, the drug treatment interference with cell cycle was investigated by monitoring the markers playing an important role in the cell cycle progression through gap phases, namely, cyclin $D 1\left(G_{1} / S\right)$ and cyclin B1 $\left(G_{2} / M\right)$. While no changes in cyclin D1 expression were observed, the decrease in cyclin $B 1$ expression indicated the cell halt at $G_{2} / M$ phase and delayed progression to mitosis. This observation was in stark contrast with other Cu-TSC complexes which caused cell cycle arrest at $\mathrm{G}_{1} / \mathrm{S}$ characterised by the decreased expression of cyclin D1 [21]. Finally, the effects of complex 2 on the PARP cleavage were investigated, which is a key event occurring during apoptosis. As expected, the expression of total PARP decreased, while the expression of cleaved PARP increased in a dose-dependent manner, indicating that complex 2 induced apoptotic cell death in A2780 cells, apoptotic cell death in A2780 cells.

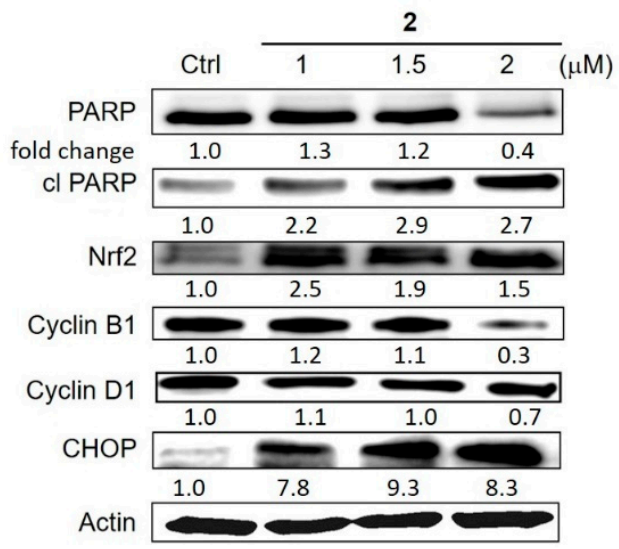

Figure 9. Western blot analysis of various proteins involved in apoptosis (PARP and cleaved PARP), cell cycle (cyclins B1 and D1), antioxidant defence (Nrf2) and ER stress (UPR) presented as a fold change in comparison with untreated cells and normalised to actin as a loading control (one representative strip is shown). A2780 cells were treated with indicated concentrations of $\mathbf{2}$ for $24 \mathrm{~h}$. Total lysates were isolated and examined by Western Blotting. The quantification of the bands was performed in Image J software.

\section{Conclusions}

While the entrance of triapine as an anticancer agent into clinical trials has revealed its limitations, due to side effects and ineffectiveness against solid tumours, the class of $\alpha$-N-heterocyclic thiosemicarbazones, and their metal complexes, have shown promising potential for further development as anticancer drugs. Herein, two triapine derivatives $\mathbf{H L}^{\mathbf{1}}$ and $\mathbf{H L}^{\mathbf{2}}$ were prepared, which act as neutral $\mathrm{N}, \mathrm{N}, \mathrm{N}$-tridentate ligands in their $\mathrm{Cu}(\mathrm{II})$ complexes, in contrast to triapine, which coordinates first-row transition metals through $\mathrm{N}, \mathrm{N}, \mathrm{S}$ donor atoms. The spectroelectrochemical experiments indicated that $\mathrm{Cu}$ complexes $\mathbf{1}$ and $\mathbf{2}$ underwent irreversible reduction of $\mathrm{Cu}(\mathrm{II})$ centres accompanied by the release of the free ligands and $\mathrm{Cu}(\mathrm{I})$ ions. On the other hand, $\mathrm{Fe}(\mathrm{III})$ complex 3 , 
where $\mathbf{H L}^{2}$ acts as monoanionic ligand, was shown to reversibly redox cycle leading to the production of the hydroxyl radical. The lead complex 2 demonstrated comparable cytotoxicity to triapine, but was less toxic to healthy cells. Based on the mechanistic investigations in ovarian cancer cells, it is likely that the non-cytotoxic $\mathbf{H L}^{1}$ and $\mathbf{H L}^{2}$ play an important role in the delivery of $\mathrm{Cu}$, resulting in the disruption of the tightly regulated intracellular balance of this essential metal ion. Thus, $\mathbf{H L}^{\mathbf{1}}$ and $\mathbf{H L}^{\mathbf{2}}$ act as effective vehicles for intracellular $\mathrm{Cu}$ delivery and may be of interest for future therapeutic development.

Supplementary Materials: The following are available online at http://www.mdpi.com/2218-273X/10/9/1336/s1, Scheme S1: Synthesis of $\mathbf{H L}^{\mathbf{1 a}}$ along with synthetic pathway, Scheme S2: Tautomeric forms of $\mathbf{H L}^{\mathbf{1}}$ and $\mathbf{H L}^{\mathbf{2}}$, Scheme S3: Atom numbering used for assignments of resonances in 1D and 2D NMR spectra of $\mathbf{H L}^{1}$ and $\mathbf{H L}^{2}$, Scheme S4: The tautomeric forms of $\mathbf{H L}^{2}$ in solution, Figure S1: Preparative HPLC trace of 1, Figure S2: ESI mass spectra of 1 after HPLC, Figure S3: Positive ion ESI mass spectrum of 3, Figure S4: The structure of the cation $\left[\mathbf{H}_{3} \mathbf{L}^{\mathbf{1 a}}\right]^{2+}$ in $\left[\mathbf{H}_{3} \mathbf{L}^{\mathbf{1 a}}\right] \mathbf{C l}_{2} \cdot \mathbf{2} \mathbf{H}_{2} \mathbf{O}$, Figure S5: pH-potentiometric titration curves for $\mathbf{H L}^{2}$, Figure S6: $\mathrm{UV}-\mathrm{Vis}$ spectra of $\mathbf{H L}^{1}$ recorded at various $\mathrm{pH}$ values, Figure S7: Time dependence of the measured spectra of $\mathbf{H L}^{2}$ at various $\mathrm{pH}$ values, Figure S8: Time dependence of the measured spectra of $\mathbf{H L}^{\mathbf{1}}$ at various $\mathrm{pH}$ values, Figure S9: Time-dependent UV-Vis spectra of (a) $\mathbf{H L}^{\mathbf{1}}$ and (b) $\mathbf{H L}^{2}$ at $\mathrm{pH}$ 2.6, Figure S10: Time-dependent UV-Vis spectra of (a) $\mathbf{1}$ and (b) $\mathbf{2}$ at various $\mathrm{pH}$ values, Figure S11: Concentration-effect curves for $\mathbf{H L}^{\mathbf{1}}, \mathbf{H L}^{\mathbf{2}}$ and $\mathbf{1 - 3}$, Figure S12: UV-Vis spectra of (a) 1 and (b) 2 in the presence of 120 equiv GSH, Figures S13 and S14: EPR spectra of DMPO spin-adducts.

Author Contributions: K.O., I.B., R.S., D.V. and I.S. performed the synthesis of ligands and complexes, as well as preparation of starting materials. M.V.B. and W.H.A. carried out the main part of biological investigations, were involved in writing the manuscript. G.G. collected X-ray diffraction data and solved the crystal structures, D.D. and P.R. carried out electrochemical and spectroelectrochemical investigations. E.A.E. and V.P. performed solution studies, A.P.-B. the experiments on R2 RNR inhibition. V.B.A. supervised the research, prepared the X-ray diffraction part, was involved in writing and editing the manuscript. All authors have read and agreed to the published version of the manuscript.

Funding: Open Access Funding by the Austrian Science Fund (FWF) via grant no. P28223-N34. Financial support by National Research, Development and Innovation Office, (Hungary) through project FK 124240 and by the Slovak Research and Development Agency (under the contract Nos. APVV-15-0053, APVV-17-0513, APVV-19-0024 and DS-FR-19-0035) and VEGA (contract No. 1/0504/20), as well as by the Singapore ministry of education (R143-000-A53-114) is gratefully acknowledged.

Acknowledgments: This article is also based on work within COST Action CA18202 supported by COST (European Cooperation in Science and Technology). D.D. would like to thank the STU Grant scheme in Support of Excellent Teams of Young Researchers for financial contribution, while V.P. to ÚNKP-19-3-SZTE-242 New National Excellence Program of the Ministry for Innovation and Technology.

Conflicts of Interest: The authors declare no conflict of interest.

\section{References}

1. Brockman, R.W.; Thomson, J.R.; Bell, M.J.; Skipper, H.E. Observations on the Antileukemic Activity of Pyridine-2-Carboxaldehyde Thiosemicarbazone and Thiocarbohydrazone. Cancer Res. 1956, 16, 167-170.

2. Kunos, C.A.; Chu, E.; Beumer, J.H.; Sznol, M.; Ivy, S.P. Phase I Trial of Daily Triapine in Combination with Cisplatin Chemotherapy for Advanced-Stage Malignancies. Cancer Chemother. Pharm. 2017, 79, 201-207. [CrossRef] [PubMed]

3. Nutting, C.M.; van Herpen, C.M.L.; Miah, A.B.; Bhide, S.A.; Machiels, J.-P.; Buter, J.; Kelly, C.; de Raucourt, D.; Harrington, K.J. Phase II Study of 3-AP Triapine in Patients with Recurrent or Metastatic Head and Neck Squamous Cell Carcinoma. Ann. Oncol. 2009, 20, 1275-1279. [CrossRef] [PubMed]

4. Choi, B.S.; Alberti, D.B.; Schelman, W.R.; Kolesar, J.M.; Thomas, J.P.; Marnocha, R.; Eickhoff, J.C.; Ivy, S.P.; Wilding, G.; Holen, K.D. The Maximum Tolerated Dose and Biologic Effects of 3-Aminopyridine -2-Carboxaldehyde Thiosemicarbazone (3-AP) in Combination with Irinotecan for Patients with Refractory Solid Tumors. Cancer Chemother. Pharm. 2010, 66, 973-980. [CrossRef] [PubMed]

5. Kunos, C.A.; Chu, E.; Makower, D.; Kaubisch, A.; Sznol, M.; Ivy, S.P. Phase I Trial of Triapine-CisplatinPaclitaxel Chemotherapy for Advanced Stage or Metastatic Solid Tumor Cancers. Front. Oncol. 2017, 7, 1-8. [CrossRef] [PubMed] 
6. Schelman, W.R.; Morgan-Meadows, S.; Marnocha, R.; Lee, F.; Eickhoff, J.; Huang, W.; Pomplun, M.; Jiang, Z.; Alberti, D.; Kolesar, J.M.; et al. A Phase I Study of Triapine®in Combination with Doxorubicin in Patients with Advanced Solid Tumors. Cancer Chemother. Pharm. 2009, 63, 1147-1156. [CrossRef]

7. Mortazavi, A.; Ling, Y.; Martin, L.K.; Wei, L.; Phelps, M.A.; Liu, Z.; Harper, E.J.; Ivy, S.P.; Wu, X.; Zhou, B.-S.; et al. A Phase I Study of Prolonged Infusion of Triapine in Combination with Fixed Dose Rate Gemcitabine in Patients with Advanced Solid Tumors. Investig. New Drugs 2013, 31, 685-695. [CrossRef] [PubMed]

8. Finch, R.A.; Liu, M.-C.; Cory, A.H.; Cory, J.G.; Sartorelli, A.C. Triapine (3-Aminopyridine-2-Carboxaldehyde Thiosemicarbazone; 3-AP): An Inhibitor of Ribonucleotide Reductase with Antineoplastic Activity. Adv. Enz. Regul. 1999, 39, 3-12. [CrossRef]

9. Aye, Y.; Long, M.J.C.; Stubbe, J. Mechanistic Studies of Semicarbazone Triapine Targeting Human Ribonucleotide Reductase in Vitro and in Mammalian Cells: Tyrosyl Radical Quenching not Involving Reactive Oxygen Species. J. Biol. Chem. 2012, 287, 35768-35778. [CrossRef]

10. Popović-Bijelić, A.; Kowol, C.R.; Lind, M.E.S.; Luo, J.; Himo, F.; Enyedy, É.A.; Arion, V.B.; Gräslund, A. Ribonucleotide Reductase Inhibition by Metal Complexes of Triapine (3-Aminopyridine-2-Carboxaldehyde Thiosemicarbazone): A Combined Experimental and Theoretical Study. J. Inorg. Biochem. 2011, 105, 1422-1431. [CrossRef]

11. Shao, J.; Zhou, B.; Di Bilio, A.J.; Zhu, L.; Wang, T.; Qi, C.; Shih, J.; Yen, Y. A Ferrous-Triapine Complex Mediates Formation of Reactive Oxygen Species That Inactivate Human Ribonucleotide Reductase. Mol. Cancer 2006, 5, 586-592. [CrossRef]

12. Knox, J.J.; Hotte, S.J.; Kollmannsberger, C.; Winquist, E.; Fisher, B.; Eisenhauer, E.A. Phase II Study of Triapine®in Patients with Metastatic Renal Cell Carcinoma: A Trial of the National Cancer Institute of Canada Clinical Trials Group (NCIC IND.161). Investig. New Drugs 2007, 25, 471-477. [CrossRef]

13. Yen, Y.; Margolin, K.; Doroshow, J.; Fishman, M.; Johnson, B.; Clairmont, C.; Sullivan, D.; Sznol, M. A Phase I Trial of 3-Aminopyridine-2-Carboxaldehyde Thiosemicarbazone in Combination with Gemcitabine for Patients with Advanced Cancer. Cancer Chemother. Pharm. 2004, 54, 331-342. [CrossRef]

14. Traynor, A.M.; Lee, J.-W.; Bayer, G.K.; Tate, J.M.; Thomas, S.P.; Mazurczak, M.; Graham, D.L.; Kolesar, J.M.; Schiller, J.H. A Phase II Trial of Triapine®(NSC\# 663249) and Gemcitabine as Second Line Treatment of Advanced Non-Small Cell Lung Cancer: Eastern Cooperative Oncology Group Study 1503. Investig. New Drugs 2010, 28, 91-97.

15. Mackenzie, M.J.; Saltman, D.; Hirte, H.; Low, J.; Johnson, C.; Pond, G.; Moore, M.J. A Phase II Study of 3-Aminopyridine-2-Carboxaldehyde Thiosemicarbazone (3-AP) and Gemcitabine in Advanced Pancreatic Carcinoma. A Trial of the Princess Margaret Hospital Phase II Consortium. Investig. New Drugs 2007, 25, 553-558. [CrossRef] [PubMed]

16. Attia, S.; Kolesar, J.; Mahoney, M.R.; Pitot, H.C.; Laheru, D.; Heun, J.; Huang, W.; Eickhoff, J.; Erlichman, C.; Holen, K.D. A Phase 2 Consortium (P2C) Trial of 3-Aminopyridine-2-Carboxaldehyde Thiosemicarbazone (3-AP) for Advanced Adenocarcinoma of the Pancreas. Investig. New Drugs 2008, 26, 369-379. [CrossRef] [PubMed]

17. Kowol, C.R.; Trondl, R.; Heffeter, P.; Arion, V.B.; Jakupec, M.A.; Roller, A.; Galanski, M.; Berger, W.; Keppler, B.K. Impact of Metal Coordination on Cytotoxicity of 3-Aminopyridine-2-Carboxaldehyde Thiosemicarbazone (Triapine) and Novel Insights into Terminal Dimethylation. J. Med. Chem. 2009, 52, 5032-5043. [CrossRef] [PubMed]

18. Jansson, P.J.; Sharpe, P.C.; Bernhardt, P.V.; Richardson, D.R. Novel Thiosemicarbazones of the ApT and DpT Series and Their Copper Complexes: Identification of Pronounced Redox Activity and Characterization of Their Antitumor Activity. J. Med. Chem. 2010, 53, 5759-5769. [CrossRef]

19. Bacher, F.; Dömötör, O.; Chugunova, A.; Nagy, N.V.; Filipović, L.; Radulović, S.; Enyedy, É.A.; Arion, V.B. Strong Effect of Copper(ii) Coordination on Antiproliferative Activity of Thiosemicarbazone-Piperazine and Thiosemicarbazone-Morpholine Hybrids. Dalton Trans. 2015, 44, 9071-9090. [CrossRef]

20. Dobrova, A.; Platzer, S.; Bacher, F.; Milunovic, M.N.M.; Dobrov, A.; Spengler, G.; Enyedy, É.A.; Novitchi, G.; Arion, V.B. Structure-Antiproliferative Activity Studies on 1 -Proline- and Homoproline-4-NPyrrolidine-3-Thiosemicarbazone Hybrids and Their Nickel(II), Palladium(II) and Copper(II) Complexes. Dalton Trans. 2016, 45, 13427-13439. [CrossRef] 
21. Ohui, K.; Afanasenko, E.; Bacher, F.; Ting, R.L.X.; Zafar, A.; Blanco-Cabra, N.; Torrents, E.; Dömötör, O.; May, N.V.; Darvasiova, D.; et al. New Water-Soluble Copper(II) Complexes with MorpholineThiosemicarbazone Hybrids: Insights into the Anticancer and Antibacterial Mode of Action. J. Med. Chem. 2019, 62, 512-530. [CrossRef] [PubMed]

22. Adsule, S.; Barve, V.; Chen, D.; Ahmed, F.; Dou, Q.P.; Padhye, S.; Sarkar, F.H. Novel Schiff Base Copper Complexes of Quinoline-2 Carboxaldehyde as Proteasome Inhibitors in Human Prostate Cancer Cells. J. Med. Chem. 2006, 49, 7242-7246. [CrossRef] [PubMed]

23. Kalaiarasi, G.; Rex Jeya Rajkumar, S.; Dharani, S.; Rath, N.P.; Prabhakaran, R. In Vitro Cytotoxicity of New Water Soluble Copper(II) Metallates Containing 7-Hydroxy-4-Oxo-4H-Chromene Thiosemicarbazones. Polyhedron 2019, 173, 114120. [CrossRef]

24. Bisceglie, F.; Musiari, A.; Pinelli, S.; Alinovi, R.; Menozzi, I.; Polverini, E.; Tarasconi, P.; Tavone, M.; Pelosi, G. Quinoline-2-Carboxaldehyde Thiosemicarbazones and Their $\mathrm{Cu}(\mathrm{II})$ and $\mathrm{Ni}(\mathrm{II})$ Complexes as Topoisomerase IIa Inhibitors. J. Inorg. Biochem. 2015, 152, 10-19. [CrossRef]

25. Da Silva, J.G.; Recio Despaigne, A.A.; Louro, S.R.W.; Bandeira, C.C.; Souza-Fagundes, E.M.; Beraldo, H. Cytotoxic Activity, Albumin and DNA Binding of New Copper(II) Complexes with Chalcone-Derived Thiosemicarbazones. Eur. J. Med. Chem. 2013, 65, 415-426. [CrossRef]

26. Palanimuthu, D.; Shinde, S.V.; Somasundaram, K.; Samuelson, A.G. In Vitro and in Vivo Anticancer Activity of Copper Bis(Thiosemicarbazone) Complexes. J. Med. Chem. 2013, 56, 722-734. [CrossRef]

27. Milunović, M.N.M.; Dobrova, A.; Novitchi, G.; Gligorijević, N.; Radulović, S.; Kožišek, J.; Rapta, P.; Enyedy, E.A.; Arion, V.B. Effects of Terminal Substitution and Iron Coordination on Antiproliferative Activity of 1-Proline-Salicylaldehyde-Thiosemicarbazone Hybrids: Effects of Terminal Substitution and Iron Coordination on Antiproliferative Activity of L-Proline-Salicylaldehyde-Thiosemicarbazone Hybrids. Eur. J. Inorg. Chem. 2017, 4773-4783.

28. Enyedy, É.A.; Primik, M.F.; Kowol, C.R.; Arion, V.B.; Kiss, T.; Keppler, B.K. Interaction of Triapine and Related Thiosemicarbazones with Iron(III)/(II) and Gallium(III): A Comparative Solution Equilibrium Study. Dalton Trans. 2011, 40, 5895-5905. [CrossRef]

29. Pogorzelska, A.; Sławiński, J.; Kawiak, A.; Żołnowska, B.; Chojnacki, J.; Stasiłojć, G.; Ulenberg, S.; Szafrański, K.; Bączek, T. Synthesis, Molecular Structure, and Metabolic Stability of New Series of N'-(2-Alkylthio-4-Chloro-5-Methylbenzenesulfonyl)-1-(5-Phenyl-1H-Pyrazol-1-Yl)Amidine as Potential Anti-Cancer Agents. Eur. J. Med. Chem. 2018, 155, 670-680. [CrossRef]

30. Al-Qtaitat, M.A.; El-Abadelah, M.M.; Sabbah, D.A.; Bardaweel, S.; Sweidan, K.; Sabri, S.S.; Mubarak, M.S. Synthesis, Characterization, and Bioactivity of New Bisamidrazone Derivatives as Possible Anticancer Agents. Med. Chem. Res. 2018, 27, 1419-1431. [CrossRef]

31. Gokhale, N.; Padhye, S.; Rathbone, D.; Billington, D.; Lowe, P.; Schwalbe, C.; Newton, C. The Crystal Structure of First Copper(II) Complex of a Pyridine-2-Carboxamidrazone-A Potential Antitumor Agent. Inorg. Chem. Commun. 2001, 4, 26-29. [CrossRef]

32. Mazur, L.; Modzelewska-Banachiewicz, B.; Paprocka, R.; Zimecki, M.; Wawrzyniak, U.E.; Kutkowska, J.; Ziółkowska, G. Synthesis, Crystal Structure and Biological Activities of a Novel Amidrazone Derivative and Its Copper(II) Complex-A Potential Antitumor Drug. J. Inorg. Biochem. 2012, 114, 55-64. [CrossRef] [PubMed]

33. Ohui, K.; Babak, M.V.; Darvasiova, D.; Roller, A.; Vegh, D.; Rapta, P.; Guan, G.R.S.; Ou, Y.H.; Pastorin, G.; Arion, V.B. Redox-Active Organoruthenium(II)- and Organoosmium(II)-Copper(II) Complexes, with an Amidrazone-Morpholine Hybrid and $\left[\mathrm{Cu}^{\mathrm{I}} \mathrm{Cl}_{2}\right]^{-}$as Counteranion and Their Antiproliferative Activity. Organometallics 2019, 38, 2307-2318. [CrossRef]

34. Arion, V.B. Coordination Chemistry of S-Substituted Isothiosemicarbazides and Isothiosemicarbazones. Coord. Chem. Rev. 2019, 387, 348-397. [CrossRef]

35. Guo, T.; Guan, R.; Zou, J.; Liu, J.; Ying, L.; Yang, W.; Wu, H.; Cao, Y. Red Light-Emitting Hyperbranched FluoreneAlt-Carbazole Copolymers with an Iridium Complex as the Core. Polym. Chem. 2011, 2, 2193-2203. [CrossRef]

36. Venuti, M.C.; Stephenson, R.A.; Alvarez, R.; Bruno, J.J.; Strosberg, A.M. Inhibitors of Cyclic AMP Phosphodiesterase. 3. Synthesis and Biological Evaluation of Pyrido and Imidazolyl Analogs of 1,2,3,5-Tetrahydro-2-Oxoimidazo[2,1-b]Quinazoline. J. Med. Chem. 1988, 31, 2136-2145. [CrossRef]

37. Freund, M.; Paradies, T. Zur Kenntnis Des Tetrazols. Ber. Dtsch. Chem. Ges. 1901, 34, 3110-3122. [CrossRef]

38. SAINT-Plus and APEX2; Bruker-Nonius AXS Inc.: Madison, WI, USA, 2016. 
39. Sheldrick, G.M. A Short History of SHELX. Acta Cryst. A Found. Cryst. 2008, 64, 112-122.

40. Burnett, M.N.; Johnson, C.K. ORTEP III: Oak Ridge Thermal Ellipsoid Plot Program for Crystal Structure Illustrations; Report ORNL-6895; Oak Ridge National Laboratory: Oak Ridge, TN, USA, 1996.

41. Irving, H.M.; Miles, M.G.; Pettit, L.D. A Study of Some Problems in Determining the Stoichiometric Proton Dissociation Constants of Complexes by Potentiometric Titrations Using a Glass Electrode. Anal. Chim. Acta 1967, 38, 475-488. [CrossRef]

42. Gans, P.; Sabatini, A.; Vacca, A. Investigation of Equilibria in Solution. Determination of Equilibrium Constants with the HYPERQUAD Suite of Programs. Talanta 1996, 43, 1739-1753. [CrossRef]

43. Voevodskaya, N.; Lendzian, F.; Gräslund, A. A Stable FeIII-FeIV Replacement of Tyrosyl Radical in a Class I Ribonucleotide Reductase. Biochem. Biophys. Res. Commun. 2005, 330, 1213-1216. [CrossRef] [PubMed]

44. Mann, G.J.; Gräslund, A.; Ochiai, E.I.; Ingemarson, R.; Thelander, L. Purification and Characterization of Recombinant Mouse and Herpes Simplex Virus Ribonucleotide Reductase R2 Subunit. Biochemistry 1991, 30, 1939-1947. [CrossRef] [PubMed]

45. Gokhale, N.H.; Padhye, S.S.; Padhye, S.B.; Anson, C.E.; Powell, A.K. Copper Complexes of Carboxamidrazone Derivatives as Anticancer Agents. 3. Synthesis, Characterization and Crystal Structure of $[\mathrm{Cu}(\mathrm{Appc}) \mathrm{Cl} 2]$, (Appc=N1-(2-Acetylpyridine)Pyridine-2-Carboxamidrazone). Inorg. Chim. Acta 2001, 319, 90-94. [CrossRef]

46. Addison, A.W.; Rao, T.N.; Reedijk, J.; van Rijn, J.; Verschoor, G.C. Synthesis, Structure, and Spectroscopic Properties of Copper(II) Compounds Containing Nitrogen-Sulphur Donor Ligands; the Crystal and Molecular Structure of Aqua[1,7-Bis(N-Methylbenzimidazol-2'-Yl)-2,6-Dithiaheptane]Copper(II) Perchlorate. J. Chem. Soc. Dalton Trans. 1984, 1349-1356. [CrossRef]

47. Enyedy, É.A.; Nagy, N.V.; Zsigó, É.; Kowol, C.R.; Arion, V.B.; Keppler, B.K.; Kiss, T. Comparative Solution Equilibrium Study of the Interactions of Copper(II), Iron(II) and Zinc(II) with Triapine (3-Aminopyridine2-Carbaldehyde Thiosemicarbazone) and Related Ligands. Eur. J. Inorg. Chem. 2010, 1717-1728. [CrossRef]

48. Kallus, S.; Uhlik, L.; van Schoonhoven, S.; Pelivan, K.; Berger, W.; Enyedy, É.A.; Hofmann, T.; Heffeter, P.; Kowol, C.R.; Keppler, B.K. Synthesis and Biological Evaluation of Biotin-Conjugated Anticancer Thiosemicarbazones and Their Iron(III) and Copper(II) Complexes. J. Inorg. Biochem. 2019, 190, 85-97. [CrossRef]

49. Saporito-Magriñá, C.M.; Musacco-Sebio, R.N.; Andrieux, G.; Kook, L.; Orrego, M.T.; Tuttolomondo, M.V.; Desimone, M.F.; Boerries, M.; Borner, C.; Repetto, M.G. Copper-Induced Cell Death and the Protective Role of Glutathione: The Implication of Impaired Protein Folding Rather than Oxidative Stress. Metallomics 2018, 10, 1743-1754. [CrossRef]

50. Panjehpour, M.; Taher, M.-A.; Bayesteh, M. The Growth Inhibitory Effects of Cadmium and Copper on the MDA-MB468 Human Breast Cancer Cells. J. Res. Med. Sci. 2010, 15, 279-286.

51. Richardson, D.R.; Sharpe, P.C.; Lovejoy, D.B.; Senaratne, D.; Kalinowski, D.S.; Islam, M.; Bernhardt, P.V. Dipyridyl Thiosemicarbazone Chelators with Potent and Selective Antitumor Activity Form Iron Complexes with Redox Activity. J. Med. Chem. 2006, 49, 6510-6521. [CrossRef]

52. Yu, Y.; Wong, J.; Lovejoy, D.B.; Kalinowski, D.S.; Richardson, D.R. Chelators at the Cancer Coalface: Desferrioxamine to Triapine and Beyond. Clin. Cancer Res. 2006, 12, 6876-6883. [CrossRef]

53. Nurtjahja-Tjendraputra, E.; Fu, D.; Phang, J.M.; Richardson, D.R. Iron Chelation Regulates Cyclin D1 Expression via the Proteasome: A Link to Iron Deficiency-Mediated Growth Suppression. Blood 2007, 109, 4045-4054. [CrossRef] [PubMed]

54. Grubman, A.; White, A.R. Copper as a Key Regulator of Cell Signalling Pathways. Expert Rev. Mol. Med. 2014, 16, e11. [CrossRef] [PubMed]

55. Park, K.C.; Fouani, L.; Jansson, P.J.; Wooi, D.; Sahni, S.; Lane, D.J.R.; Palanimuthu, D.; Lok, H.C.; Kovačević, Z.; Huang, M.L.H.; et al. Copper and Conquer: Copper Complexes of Di-2-Pyridylketone Thiosemicarbazones as Novel Anti-Cancer Therapeutics. Metallomics 2016, 8, 874-886. [CrossRef] [PubMed]

56. Sîrbu, A.; Palamarciuc, O.; Babak, M.V.; Lim, J.M.; Ohui, K.; Enyedy, E.A.; Shova, S.; Darvasiová, D.; Rapta, P.; Ang, W.H.; et al. Copper(II) Thiosemicarbazone Complexes Induce Marked ROS Accumulation and Promote Nrf2-Mediated Antioxidant Response in Highly Resistant Breast Cancer Cells. Dalton Trans. 2017, 46, 3833-3847. [CrossRef]

(C) 2020 by the authors. Licensee MDPI, Basel, Switzerland. This article is an open access article distributed under the terms and conditions of the Creative Commons Attribution (CC BY) license (http://creativecommons.org/licenses/by/4.0/). 